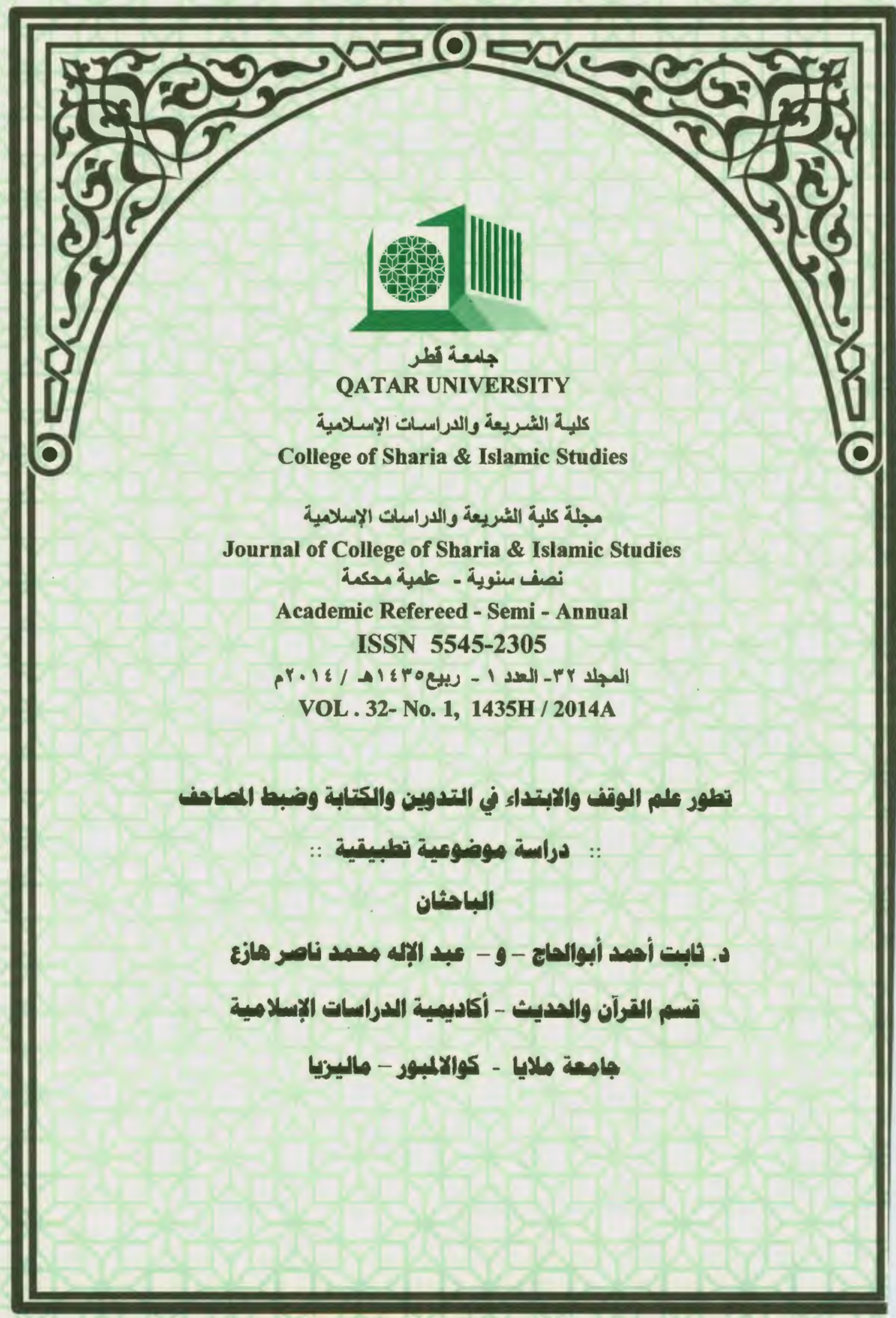




\section{ملخص البحت:}

تناول الباحثان في هذه الدراسة مفهوم الوقف وأنواعه، مع التذكير بأممية هذا العلم

وفوائده، ومعرفة الأدلة على مرأعاته من الكتاب والسنة والإجاع، وعرّنا بعلماء هذا

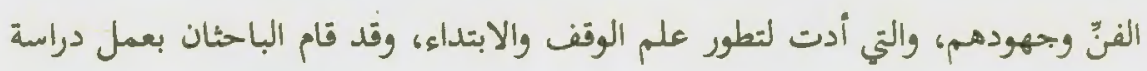

مقارنة - في المبحث الثالث- عن طريق عمل جلاولٍ توضيحيّة لسورة الفاتحة

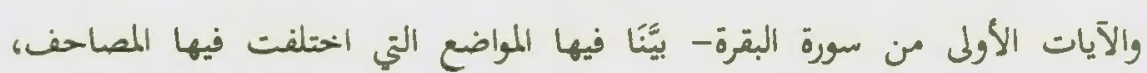

وتنوعت فيها أقوال علماء الوقف، مع ذكر نوع الوقف عند كلٍ منها،مع المقارنة بين

أقوال علماء هذا الفن، زيادةً في الإيضاح والتقريب والتسهيل والترتيب، وسلك الباحثان

المنهجين: الاستقرائيّ الموضوعي، والمنهج التطبيقي؛ من خلال ربط الجانب العلمي

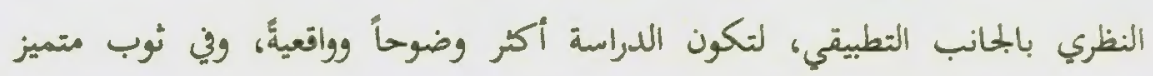

جديد.

\section{Abstract}

In this research show the researchers to the concept of endowment and types, with a reminder of the importance of this science and its benefits, and see evidence of it from the Quran and Sunnah and consensus, with the definition of the most important scientists who contributed to the development of science of stopping and starting, and the researchers conducted a study comparing - in the third section through the work tables illustrate positions that differed by the Koran, and the varied where sayings scholars Endowment through Surat AlFatihah and the first verses of Surat AL-Baqrah, together with the type of endowment at each of them, with the comparison between the comments of the scholars of this art, for further clarification and convergence and facilitation and arrangement. 


\section{: Lat}

الجمد الله حمداً لا انقطاع لراته، ولا إقلاع لسحائه، حماً يكون لإنعامه بمازياً،

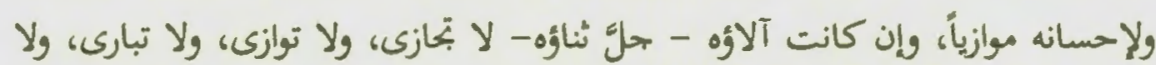
تجارى.

والصلاة والسلام على من جاء بأمته من الظلمات إلى النور، وأفاء عليهم الظل بعد الحرور، وعلى آله وصحابته مقاليد السعادة ومفاتيحها، ومجاديع البركة ومصابيحها، أعلام الإسلام، وأمان الإيمان، وعلى التابعين، وتابعيهم بإحسان. أما بعد: فإن خير كالام استُنهِفْنَا إلى وصال عقل حبائله، والوقوف على مدلول دلاثله، لكالامّ نزلَ به الروح الأمين، على قلب سيدنا محمد - صلى الله عليه وملم ليكون من المنذرين، بلسان عربي مبين. وإن علم الوقف والابتداء من أرسخ علومه أصلاً، وأبسقها فرعاً، وأكرمها نتأجاً، وأنورها سرأهاً.

\section{أمبح الموضوع وأسباب المتباره:}

هذا العلم هو حلية التلاوة، وزينة القارئ، وبلاغ التالي، وفهم المستمع، وفنحر العالم، وبه تعرف كيفية أداء القرآن، فيتبين به الوقف والابتداء، وبه يُعرف الفرق بين

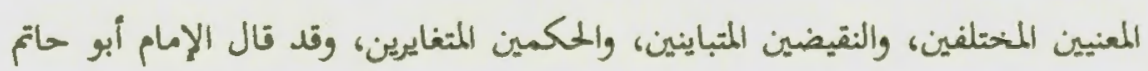
السجستاني (ت:00:هـ): لامن لم يعرف الوقف، لم يعلم ما يقرأ ) (1).وقال الإمام

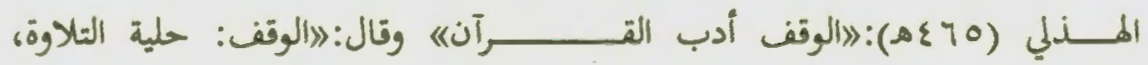


وتحلية الدراية، وزينة القارئ، وبلاغة التالي، وفهم المستمع، وفخرٌ للعالم.وقال علقمة:

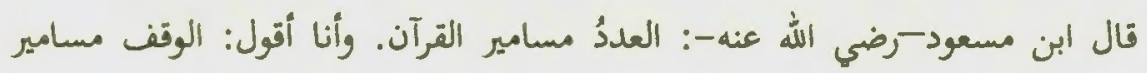

$$
\text { القرآن ودمره (2) }
$$

| المعرفة الوقف والابتداء متأكدة غاية التاكيد؛ إذ لا يتبين معنى كلام اللّه ويتمّ

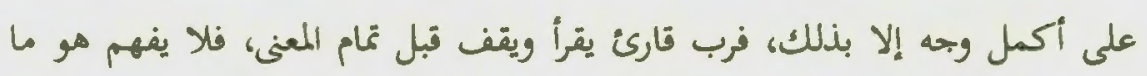

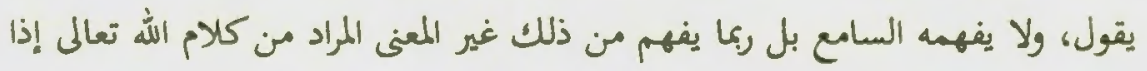

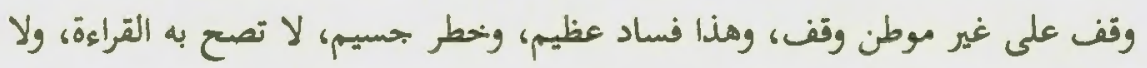
تحل به التاوة 《) "( وقد حض العلماء على تعلم الوقف والابتداء والعمل به، وبينوا عظيم فضيلته. وبإحسان الوقف -كي قراءة القرآن- تتبدَّى للسامع فوائده الوافرة، ومعانيه

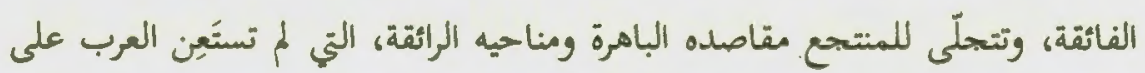

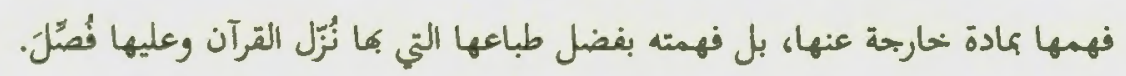
ولقد دلت النصوص والآيار على منية تعلم الوقوف، بل هو إجماع من الصحابة رضي الله عنهم، وصح بالثواتر تعلمه والاعتناء به عن السلف الصالح كما سيأي. وحض العلماء على تعلم الوقف والابتداء والعمل به، وبينوا عظيم فضيلته.

(1) الصفاقسي (ت:111/11)، أبو المسسن علي بن محمد بن سالم النوري ، تحقيق، النيفر،

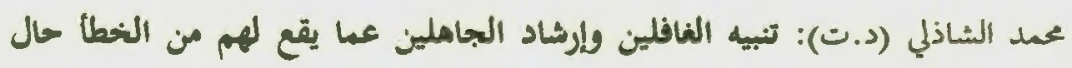

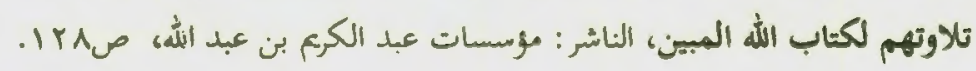




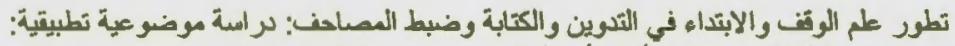

ولأمية هذا العلم اشترط كير من العلماء على الجيزيز ألا يجيز أحداً إلا بعد معرفته الوقف والابتداء")

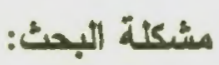

ومع ما تقدم من جهلالته، و اعتناء القراء السالفين به إلا أنَّ هذا العلم أصبح

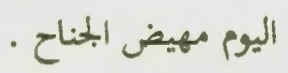

فلقد فرط الدارسون في تعلمه وتعليمه تفريطاً بليغاً، وأجدب مذا الفن في كيرٍ

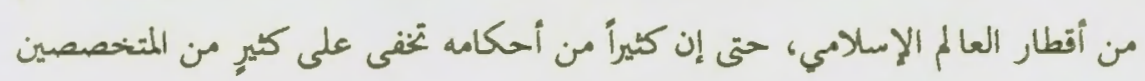
فضلأ عن غيرهم.

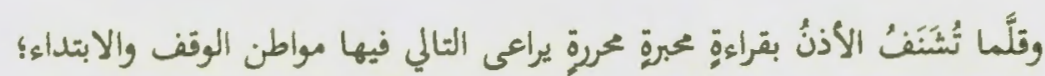

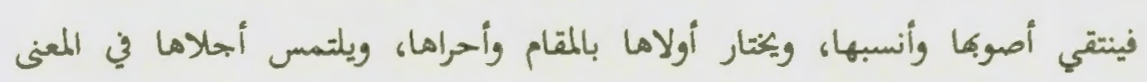

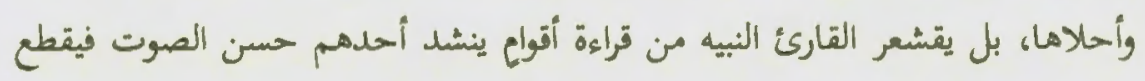

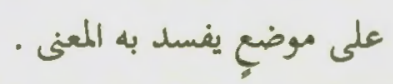

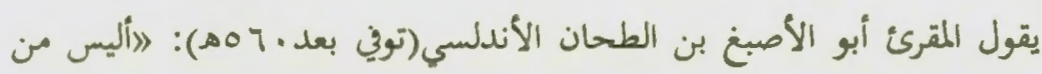
المخطأ العظيم أن يقرأ كتاب الله تعالى فيقطع على القطع يفسد به المعنى ..یه(r).

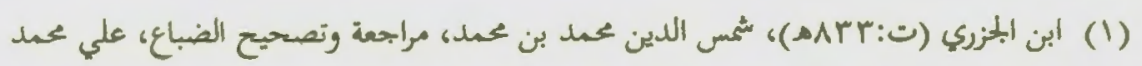

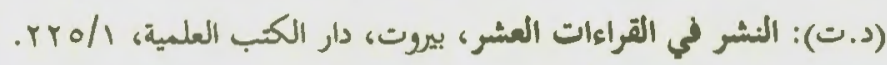

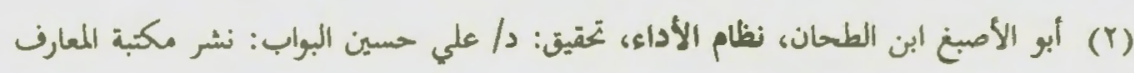

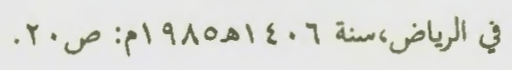


وذلك نو قوله تعالى: \}أولكك أصحاب النار هم فيها خحالدون\{ هنا الوقف، ولا يجوز أن يوصل ذلك بقوله: \}والذين آمنوا وعملوا الصالحات . ..

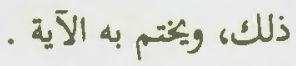

\section{أهداف البحث:}

يسعى الباحثان من خحلال هذا البحث إلى تحقيق الأهداف التالية : 1- إظهار أممية هذا الفن الجليل، وشرفه ومنزله لتعلقه بكتاب الله المحيد .

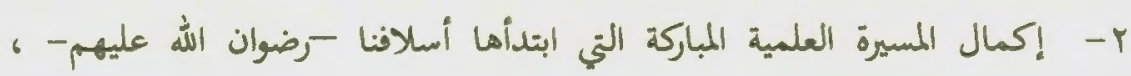

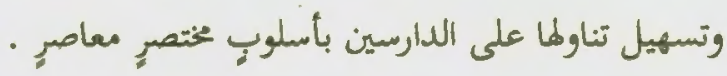
r- معرفة ما إذا سيعود تدريس هذا النوع من العلم بالعائدة المسنى والفائدة المرجوة على الدازسين في فهم معاني الكتاب العزيز وتدبره وتعليمه.

ع - رغبة الإطلاع على ما عليه الناس في القطرين: المشرقي، والمغري، وما أحلدثوه في

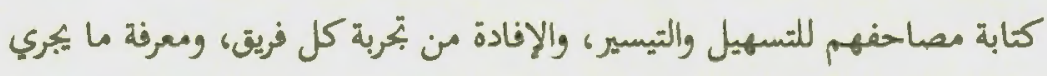

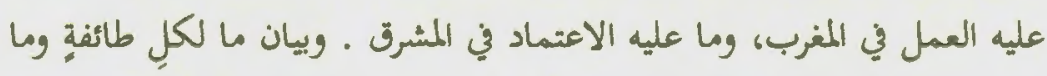

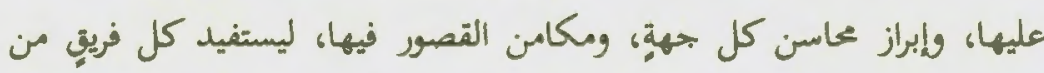

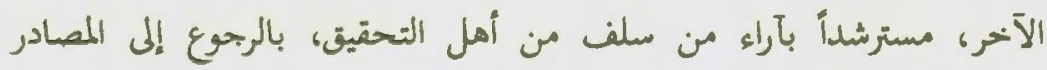

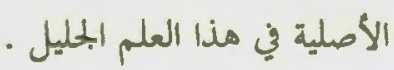

\section{هيكل البحث :}

يشتمل هذا البحث على:مقدمـــة، ونلائة مباحث، وضحاتمــة، على النحو 
المبحث الثالث: جدول توضيحي للوقوف- مواضعها وعلاناتما- في الصفحات

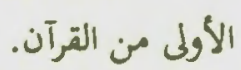

ثم حلص الباحث إلى اللماتمة، وفيها : ملخص البحث، وأهم النتائج، والتوصيات .

\section{منهن}

سلك الباحثان المنهجين الثاليين:

$$
\text { الأول: الاستقرّئي: الموضوعي: }
$$

وذلك بممع النصوص الثشرعية التي لها علاقة بموضوع البحك، واستقراء

أقوال العلماء في الموضوعات ذات العلاقة، ولذلك لتحديد موضوعات البحث

$$
\text { وعناصره. }
$$

\section{الماني: المنهج اليطبيقي:}

من خحلال ربط الجانب العلمي النظري بالجانب التطبيقي، لتكون

$$
\text { الدرامسة أكتر وضوحاً وواقعيةٌ، في ثوب جديد متميز. }
$$

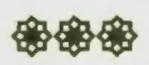




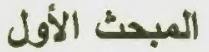

تعزيف الوقتف والابتّاء، ومصطلحاتهما، وحكمها

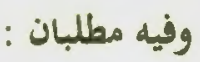

$$
\text { المطب الأول }
$$

\section{تعريف المقتف والابتداء ، ومصطاتحاته}

\author{
أولأ : تعريف الموتَ لغةٌ واصطلاهاً: \\ أما الوقف "فمعناه لفةً : الكف عن القول والغعل، أي تركهما .ويجمع على \\ وقوف وأوقاف، وربما جُع الجممع فقيل: وقوفات، والوقف في القراءة : قطع الكلمة عمًا \\ بعدها.والموقِف: الموضِع الذي تَقَفِ فيه حيث كان. \\ (1) انظر : ابن فارس (ت: 0وبهـ)، أبو المسين أحمد الرازي، تحقيق هارون، عبد السلام

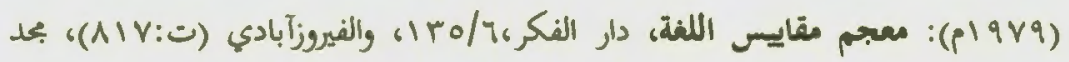

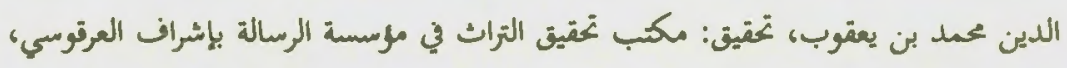

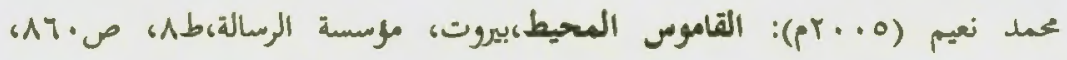 \\ الزبيدي، أبو الفيض محمد مرتضى(ت ه . 1 اهـ)، تحقيت: بحموعة من المحققين (د.ت): تاج

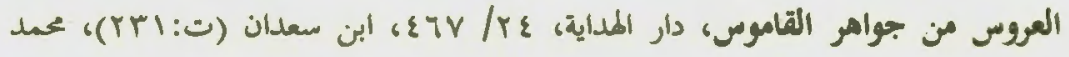

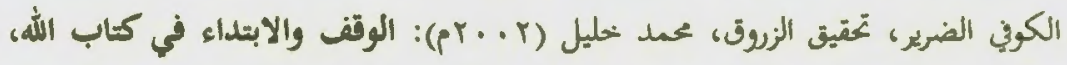

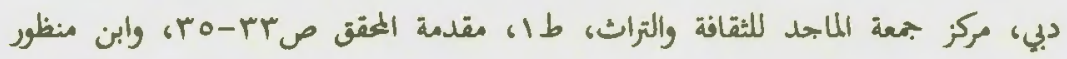


وأشهر تعاريف الوقف اصطلاحاً وأجعها هو تعريف الإمام ابن الجزري (ت

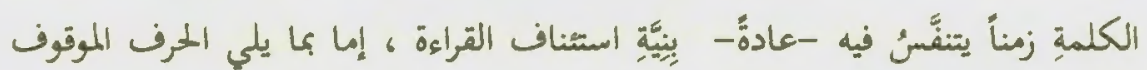

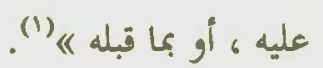

\section{الثقب بين المثت والقطع والسكت:}

قال العلامة الضباع(ت:بVT Iهـ): "الوقف والسكت والقطع: كان كير من المتقدمين يطلقون هذه الثلائة ويريدون بها الوقف غالباً، وفرق بينها المتأخرون وجماعة

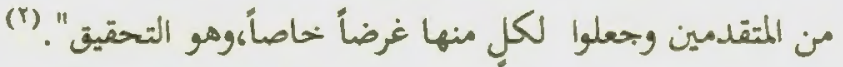

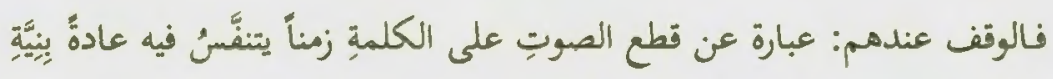
القراءة لا بِنيَّة الإعراض. والقطع : عبارة عن قطع القراءة رأساً، فهو كالانتهاء(r).

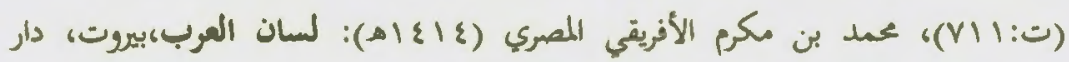

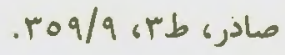

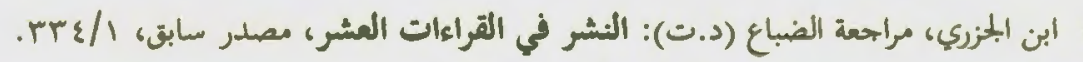

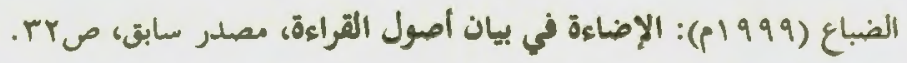

فالقارئ به كالمعرض عن القراءة، والمنتقل منها إلى حالة أخرى سوى القراءة؛ كالذي يقطع

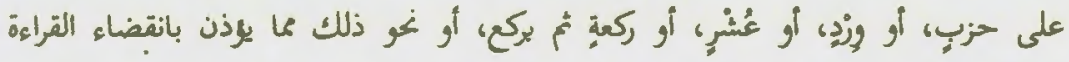

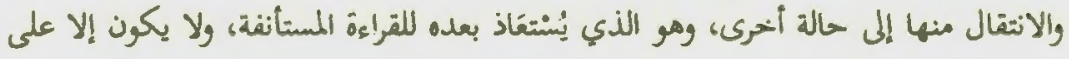

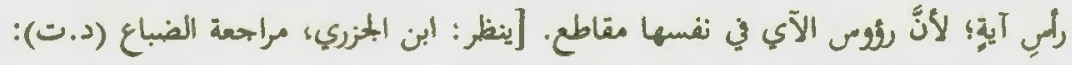

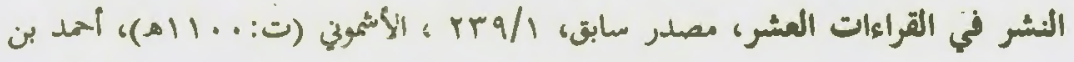




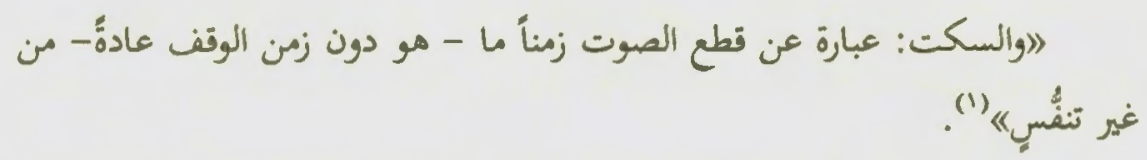

ثُانياً : تعريف الابتداء لغنة واصطلاحماً

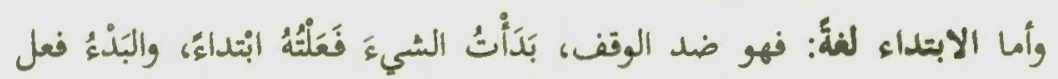

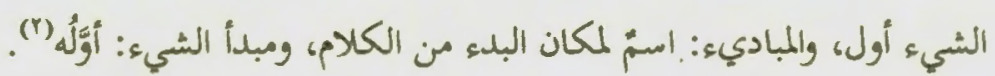

والابتداء احطلاحاً: لهو الثمروع في الكلام بعد قطع أو وقفه).

عبد الكريم، تحقيق: العدوي، شريف أبو العلا (r ... Pم): منار الهلدى في بيان الوقف والابتلاء ومعه المقصد للفخيص ما في المرشد كلأنصاري، بيروت، دار الكتب العلمية،

. [r\&ص

(1) وإذا نظرت إلى الثلالة بتحها تشترك في تطع الصوت زمناً . وينفرد السكت بكونه من غير

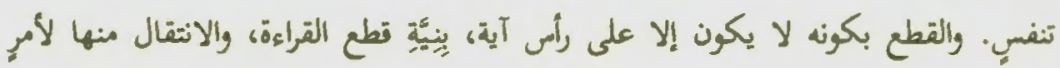

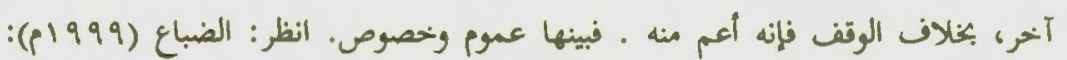

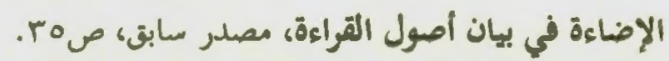

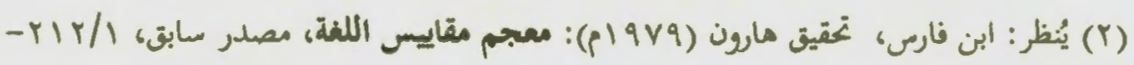

rir

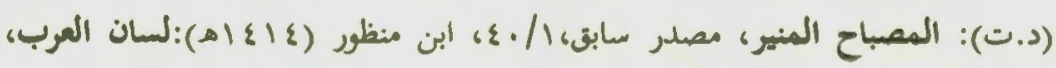

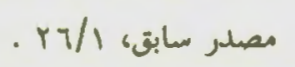

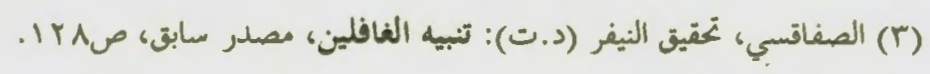


تطور علم الوتث والابتداء في التكوين والكتابة وضيط المصاحف: برامبة موضوعية تطبيقية:

أي أن الابتداء - في عُرف القراء- يعني: استئناف القراءة بعد الوقف أو

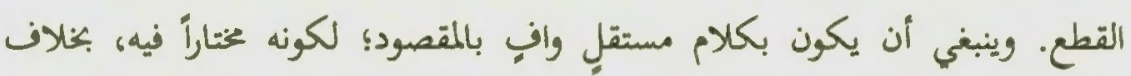
الوقف فقد يكون مضطراً إليه، وفي العادة لا يكون الاضطرار في الابتداء") وإذا كان الابتداء بعد قطع فينبغي أن يكون غير مرتبط بما قبله في المعنى. وهو في أقسامه كأقسام الوقف: إما أن يكون صالحاً للابتداء، وإبا ألا يكون، ويتفاوت تماماً وكفايةٌ وحسناً وقبحاً بكسب التمام وعدمه، وفساد المعنى وإحالته (r).

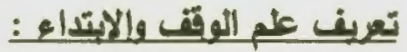

مو "علمّم يعرف به القارئ المواضع التي يصلح الوقف عليها أو لا يصلح؛

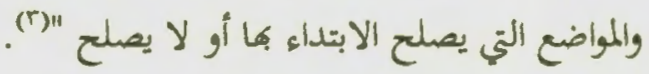

\section{أسماء عثم الئقت والايتّاء :}

مما يمسن توجيه النظر إليه هاهنا أن هذا المصطلح [الوقف والابتلداء] قد غلب

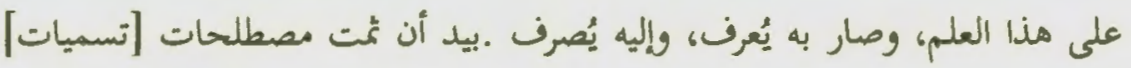

(1) انظر: ابن الجزري، مراجعة الضباع (د.ت): النشر في القراءات العشر، مصدر سابق،

$$
\text { .rr./ }
$$

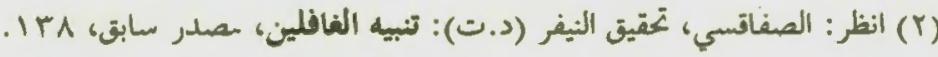

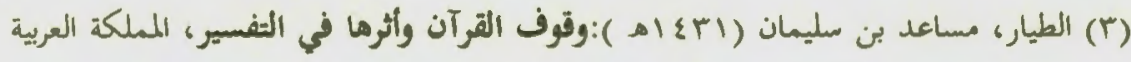

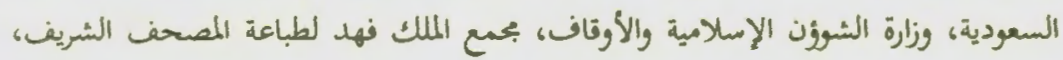




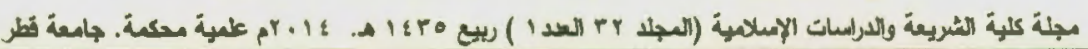

أخرى استعهلها بعض أمساطين هذا الفن، وعنونوا بها كتبهم، من ذلك:القطع والائتناف -المقاطع والمبادئ-المقطوع والموصول - التهام.

$$
\text { المطاب الثاني }
$$

حكم تعم هأ العم - علم المقف والابتّاء- وإلعل به، وإهميته

\section{الأصل في مراعاة الوقت والابتداء}

لا ريبَ أن العربَ قد اهتمتْ بالوقفِ في كلامِها، وذلك نابِ من فصاحتهِا،

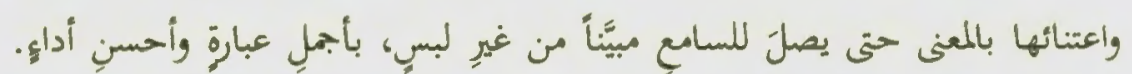
"وهذا من أشدُّ ما حرصت عليه العرب في أداء عبارتما، واهتمت له في كلامها شعرِّه

ومن ذلك ما ذكره النحاس(ت:^rrهـ) عن أبي بكر الصديق(rاهـ)رضي الله

عنه أنه قال لرجلِ معه ناقة: أتبيعها بكذا؟ فقال: لا، عافاك الله، فقال: لا تقل هكذا، ولكن قل: لا، وعافاك الله.وإذا اسُتبحح مثل هذا في كلام يردده بعضنا، فاستقباحه واستفحاشه في كتاب الله تعالى أولى، وهو بالتوبيخ فيه والمقت عليه أحق وأحرى. (1)

(1) ينظر: ابن النحاس (ت:ArAه)، أبو جعفر ألمد بن محمد بن إسماعيل تحقيق المطرودي،

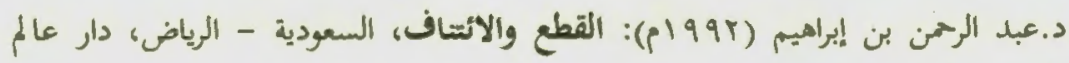

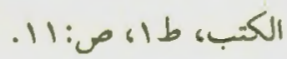


قلتُ: وهذا فيه إشارةٌ جليةً لما يُسمى اليوم بـ الفواصل وعلامات الترقيم. التي

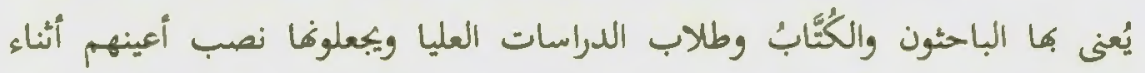

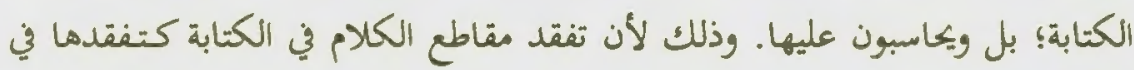

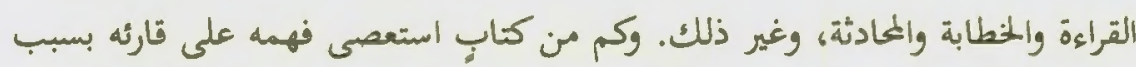

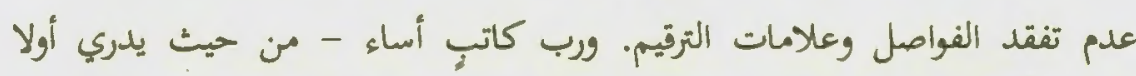
يدري- بسوي استخدامه لتلك العلامات والفواصل أو إممالها وعدم تفقدها.

"ومما يبين ذلك ويوضحه ما رواه تميم بن طرفة(ت: ع9هـ) -رحمه الله-، عن

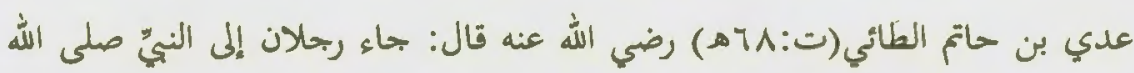

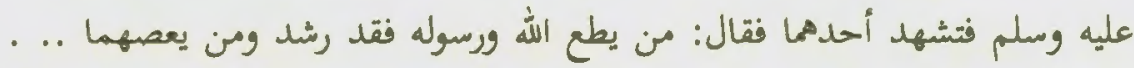

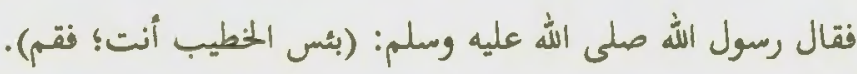
قال أبو جعفر النحاس:"كان ينبغي أن يصل كلامه فيقول: (ومن يعصهـا فقد

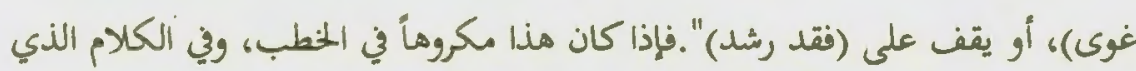

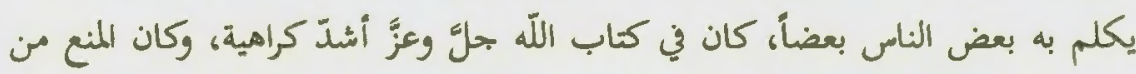

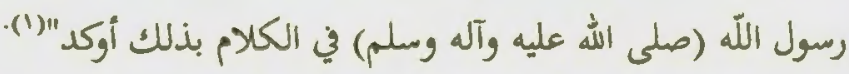
وقل اختار العلماء وأئمة القراء تبيين معاني كلام الله عزَّ وجلك، وجعلوا الوقف

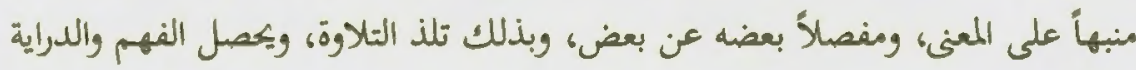
ويتضح منهاج المداية"') (r)

(1) ينظر : ابن النحاس، تحقيق ألمطرودي (Y991 1): القطع والائنساف، مصدر سابق، ص 11 (1).

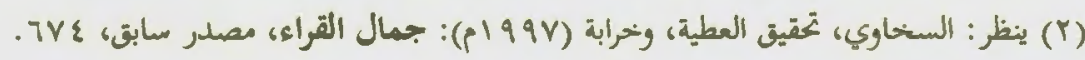


فبمعرفة هذا العلم يكصل للمسلم نصيب وافر من المعرفة بالقرآن، فيتمكن من

إدراك معانيه، واستباط أحكامه، ومعرفة إعرابه، وفهم معانيه (1) .

وهى كذلك ظاهرة عجيية، فالوقف على الكلمة القرآنية يؤدى إلى معنى لا

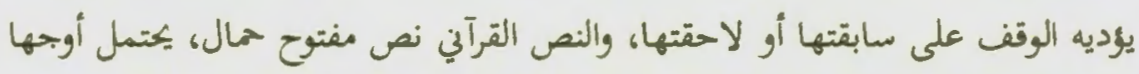

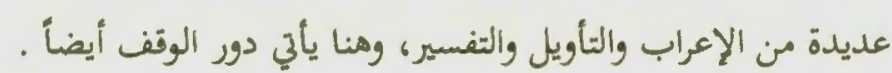

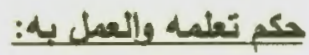

يسنُ للقارئ أن يتعلم الوقوف (1)، ويستحب له أن يتعمد المقاطع المرضية

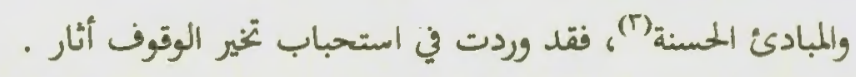

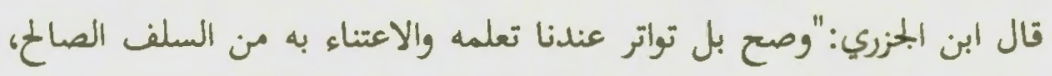

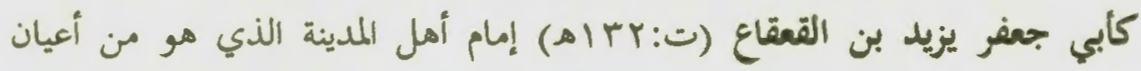

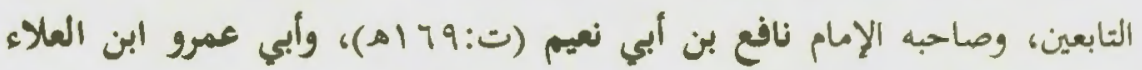

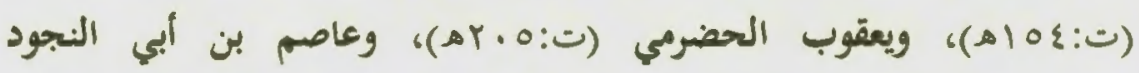

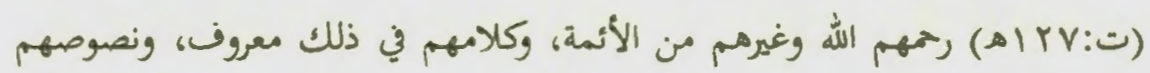

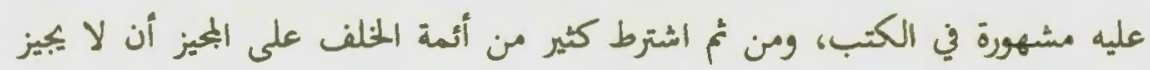

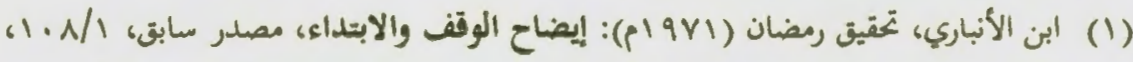

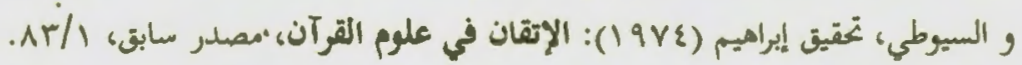

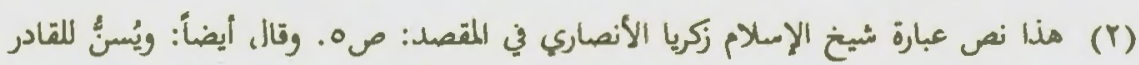

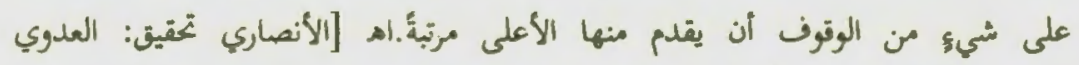

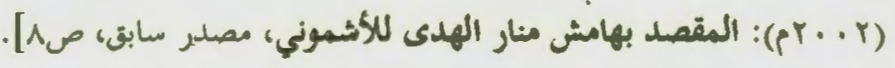

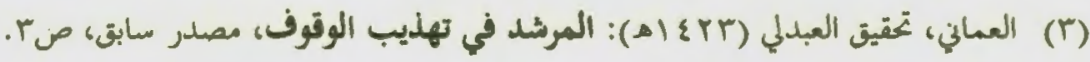

$$
\begin{aligned}
& -r 9-
\end{aligned}
$$


أحداً إلا بعد معرفته الوقف والابتداء. وكان أيمتنا يوقفوننا عند كل حرف؛ ويشيرون إلينا فيه بالأصابع ، سنة أخذوها كذلك عن شيوخهم الأولين. رحمة الله عليهم (1) "أجمين

\section{الأدية من الكتاب وإلسند والاجماع والآثّار التولردة عن الصحابة والتتابعين على}

\section{مراعاة الصوتف بالايتداء:}

قد دلت الأدلة على أهمية مراعاة الوقف والابتداء؛ وثبت واشتهر اعتناء السلف

$$
\text { بذلك ، ومن ذلك: }
$$

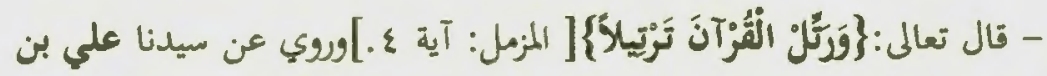
البي طالب (•عه) - رضي الله عنه - أنه منل عن ذلك فقال: "الترتيل: معرفة

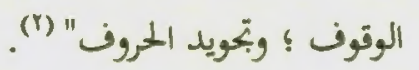

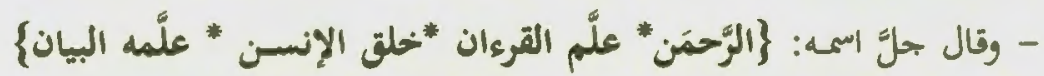
قال ابن النحاس: 》 فمن البيان تفصيل الحروف، والوقف على ما قد تَّ، والابتداء بما

$$
\text { يجسن الابتداء به، وتبيين ما يجب أن يُجتنب من ذلك.ه"(r)". }
$$

(1) ابن الجزري، مراجعة الضباع (د.ت): النشر في القراءات المشر، هصدر سابق، / / مro.

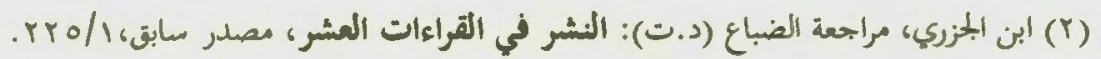

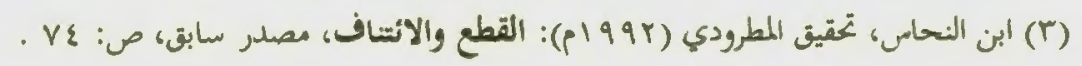


فعن أبي بكرة (ت:مهـ رضي الله عنه [أن جبريل - عليه السلام - أتى النبي

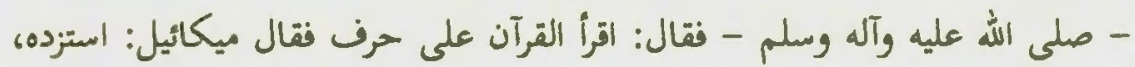

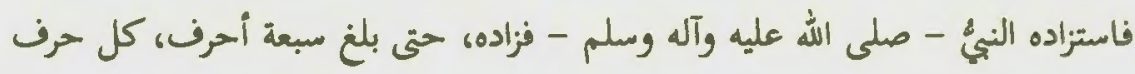

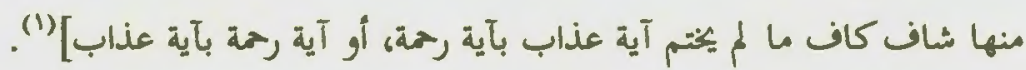
قال أبو جعفر النحاس: "فهذا تعليم التمام توقيفاً من رسول الله - صلى الله

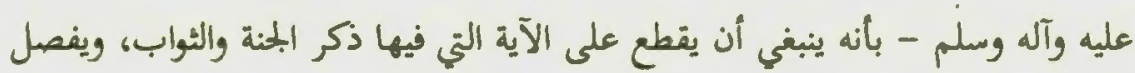

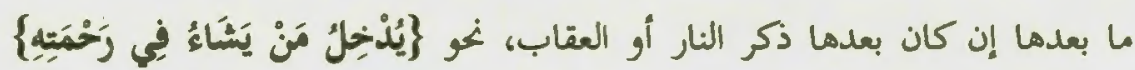
(الإنسان: آم) ولا ينبغي أن يقول

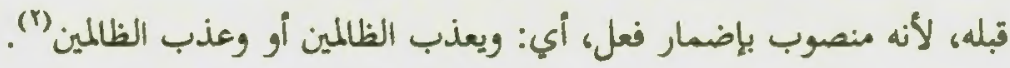
وقد حكى ابن النحاس والداني وغيرما، إجماع العلماء على أممية مراعاة الوقف

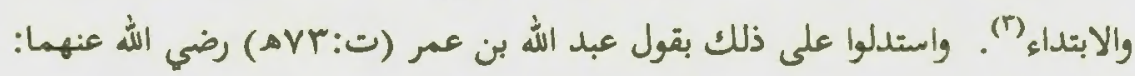

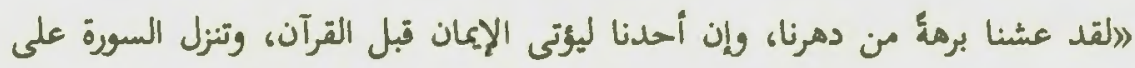

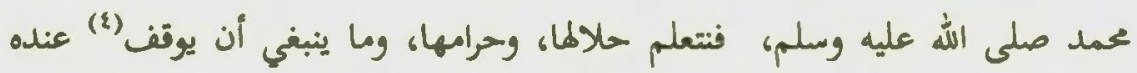

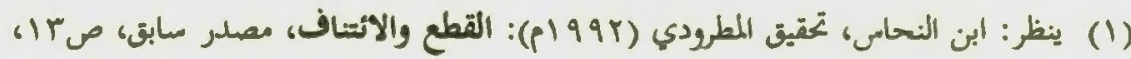

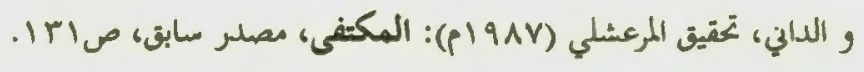

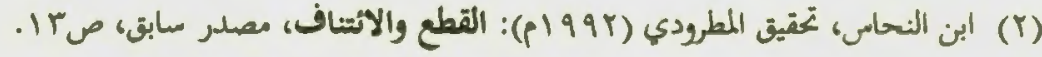

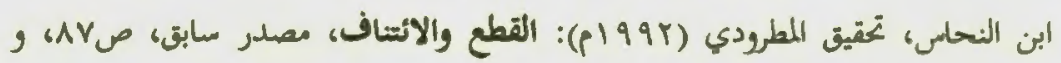

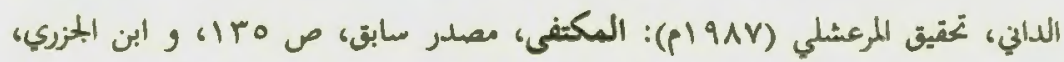

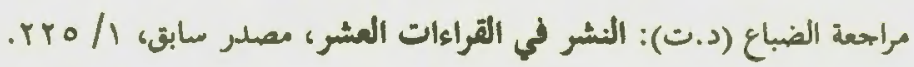

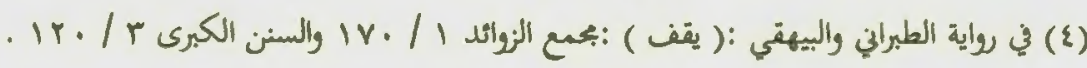


منها، كما تتعلمون أنتم اليوم القرآن ، ولقد رأينا اليوم رجالاً يؤتى أحدهم القرآن قبل

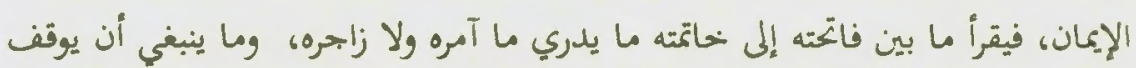

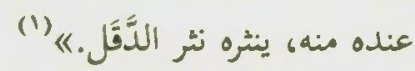

والشاهد منه قوله:لاوما ينبغي أن يوقف عنده منها《. فهذا الأثر يدل على أفم كانوا يتعلمون الأوقاف كما يتعلمون القرآن، وإن هذا إجماع من الصدر الأول،وبه

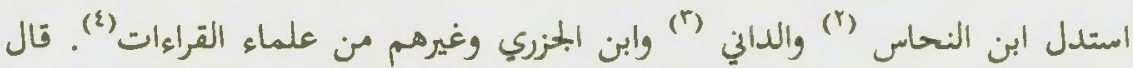
الححافظ ابن الجزري في النسر:ا..وفي كلام ابن عمر برهان على أن تعلمه إجماع من الصحابة رضي الله عنهم. وصحَّ بل تواتر عندنا تعلمه والاعتناء به من السلف الصالح رضوان الله عليهم.")

(1) التَّقَل:بفتح الدال المهملة بعدها قاف مفتوحة وهو رديء التمر ويابسه، و ما ليس له امبم

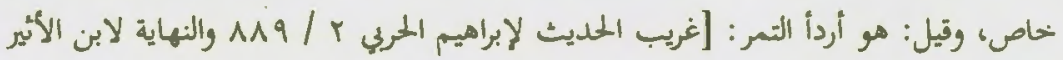

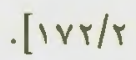

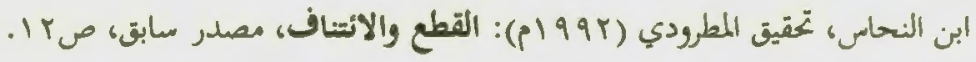

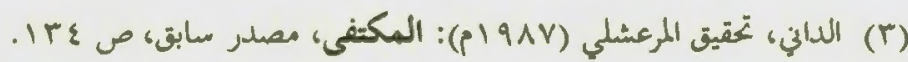
(ع) ينظر : ابن الجزرزي ، مراجعة الضُباع (د.ت): النشر في القراءات المشر، مصدر مابق،

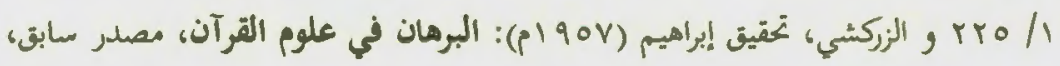


ذكر بعض الآثار الواردة عن الصحابة والتابعين الدالة على مراعاة الوقف

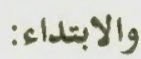

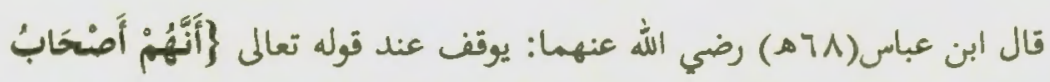

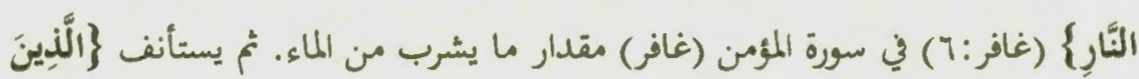

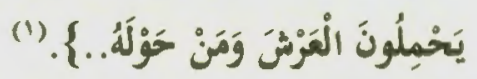

وروى الإمام أبو عمرو الداني (ت:ع؟عه)- رحمه الله - عن ميمون بن

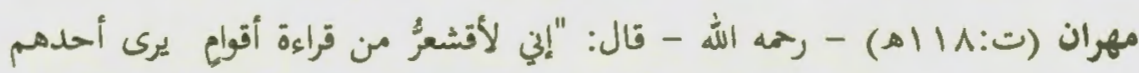

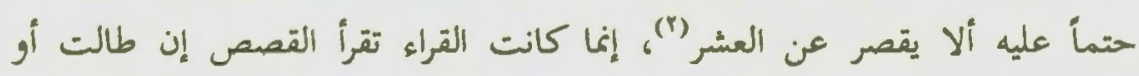

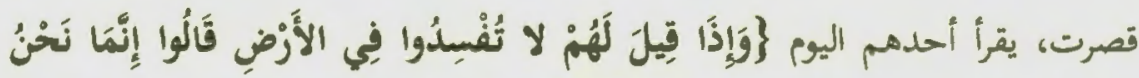

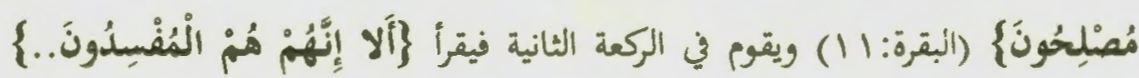

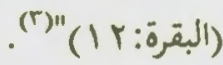

ثم قال أبو عمرو الداني رحمه الله تعاللى: لهذا يبين أن الصحابة رضي الله

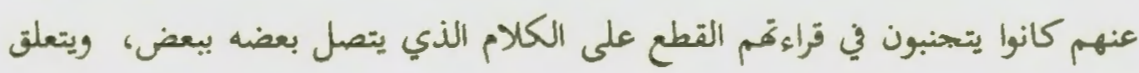

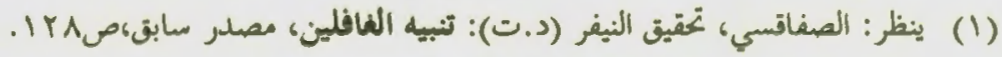

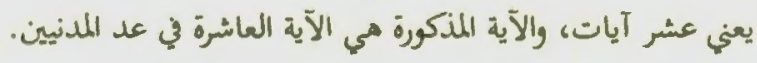

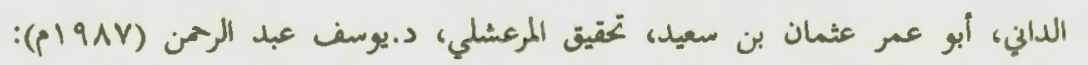

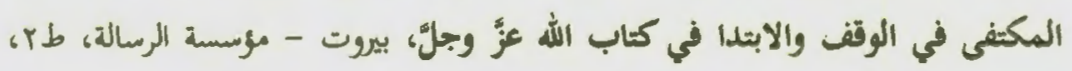


تطور طم الوثت والابتداء في التُوين والكتابة وضبط المصاحف: درامة موضو عية تطبيقية:

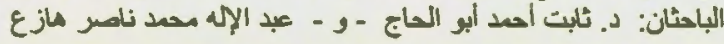

آخره بأوله، لأن ميمون بن مهران إنما حكى ذلك عنهم، إذ هو من كبار التابعين،

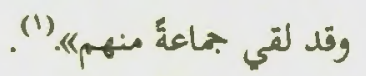

وقد أنكر مثل هذا عمر بن عبد العزيز (1 اهـ)- رحمه الله تعالى - على

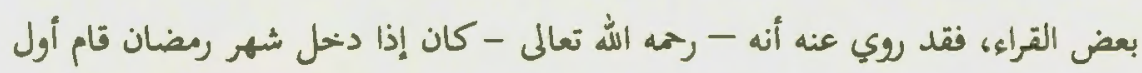

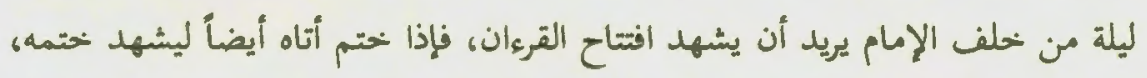

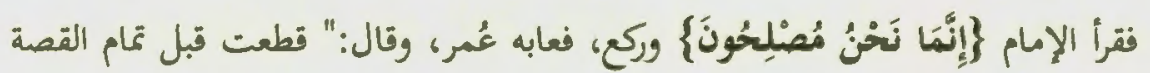

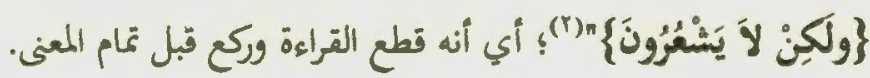

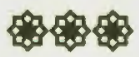

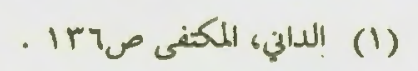

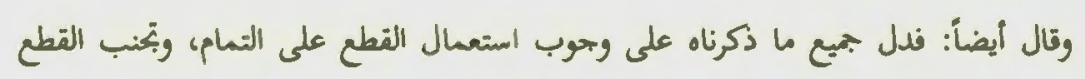

$$
\text { على القبيح، وحض على تعليم ذلك وعلى معرفته. }
$$

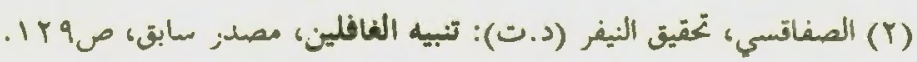




\section{المبحث الثاني \\ هراحل التجبيد في هi الطم}

\section{نشأة هذا الانن، رتطوره، ويداية طهرe تدويناً:}

المرحلة الاولى : عهد الصحابة الكرام"رضوان الله عليهم":

كان الصحابة - رضوان الله عليهم - يهتمون عند قراءة القرآن بمراعاة

الوقف والابتداء، ويتناقلون مسائله مشافهةً، ويتعلمونه مع القراءة،وقد ذكرنا حديث

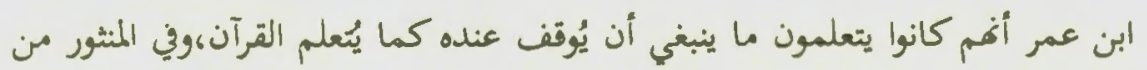

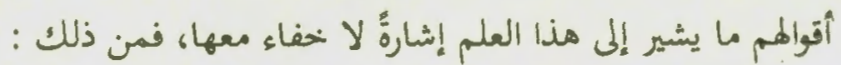

ما لرواه ابن جرير في تغسيره(") والحاكم في المستدرك (1) وابن النحاس: لا أنَّ

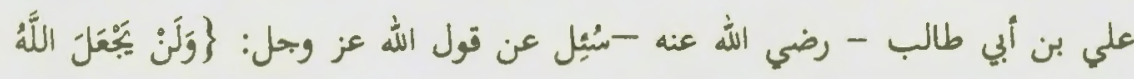

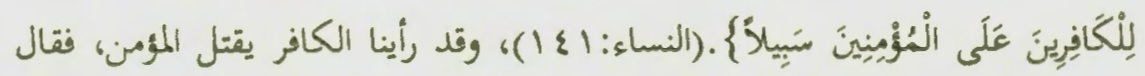

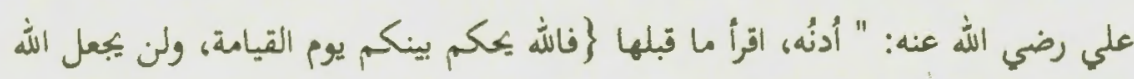

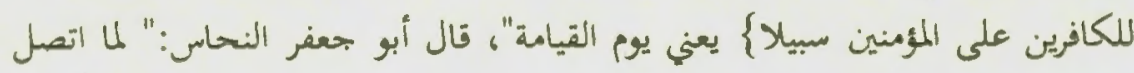

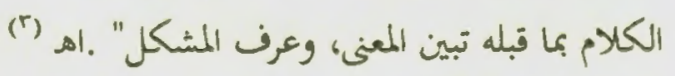

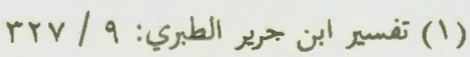

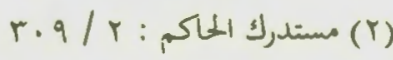

$$
\begin{aligned}
& 91 \text { (r) (r) النحاس، القطع (r) }
\end{aligned}
$$


وعلى هذا فالأولى ألا يقطع على قوله \}يوم القيامة\{ بل توصل بما بعدها ويكون التطع على: \}ون يجعل الله للكافرين على المؤنين سبيلاً. بـ، وهذه الآية يظهر

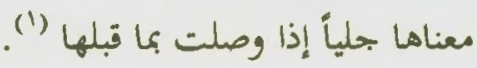

ورد عن ابن عباس رضي الله عنهما أيضاً: في قوله \}والذين آمنوا بالله ورسله

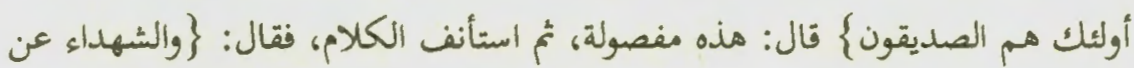

$$
\text { ربهم لهم أجرهم ونورهم }
$$

المرحلة اللانية: التابعون وتابعوا الثابعين:

واهتم به التابعون من بعدهم، وقل وردت عنهم آثار كثيرة، وعبارات وفيرة، تلل على اعتنائهم بمراعاة الوقف والابتداء، ويُستنط منها فوائد في التفسير،وإليك طرفاً من الأمثلة الواردة عنهم، الدالة على ضرورة الاعتناء هذا العلم، تنبئ عن غيرها، وتشير إلى

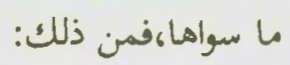

ما صع عن الشعبي(ت: r • 1ه) أنه قال:"إذا قرأت \}كل من عليها فان فلا

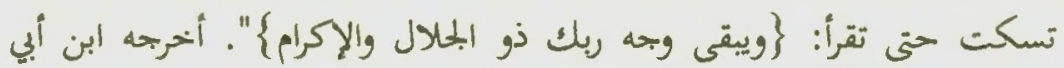
(r)

وروى عن أبي عبد الرحمن السلمي أنه كان يستحب أن يقف جقَالُوا يَا وَيْلَنا تَنْ

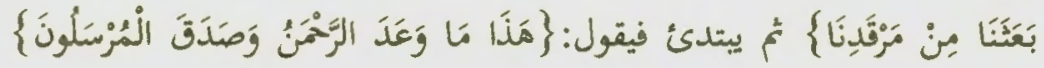

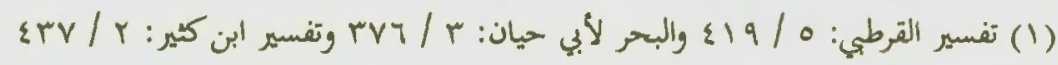

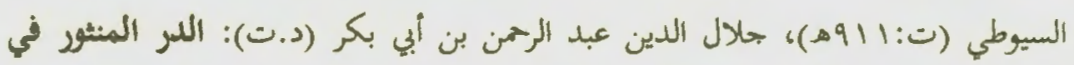

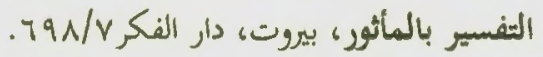


|يس:مأr| أراد أن يفرق بين كلام الكفار، وجواب الملائكة. ومن أجل هذا فإن حفعاً ' 'الراوي عن عاصم يسكت هنا سكتةً لطيفةً.

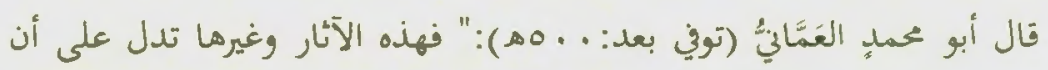

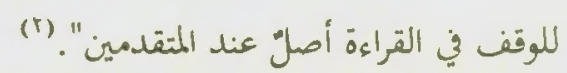
المرحلة الدالئة: مرحلة القرآياءلعشر وتلاميذهم:

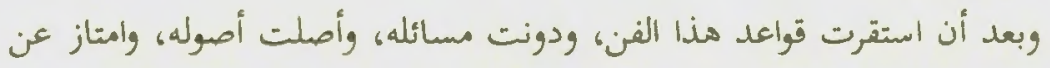

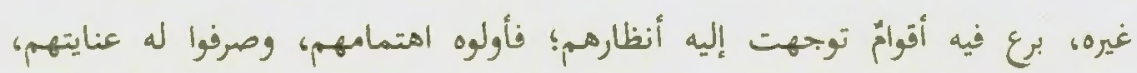

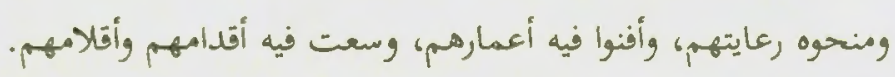

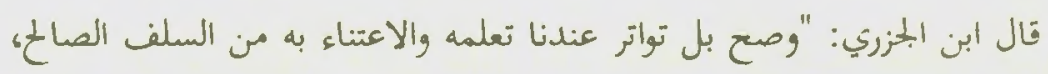

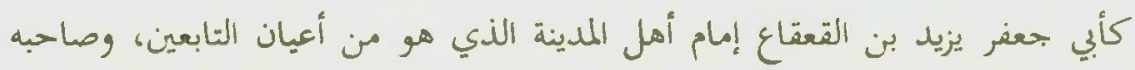

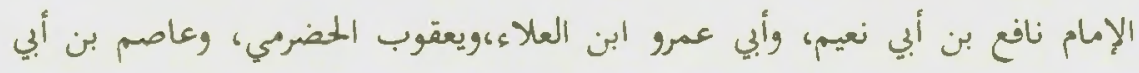

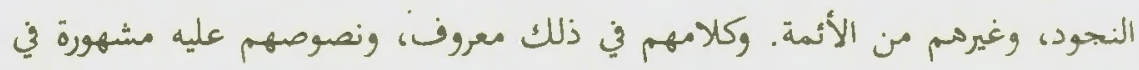
(r) الكتب (النجون

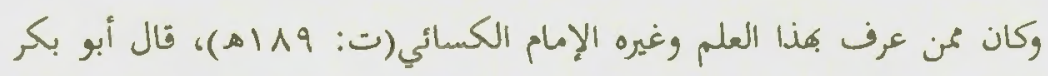

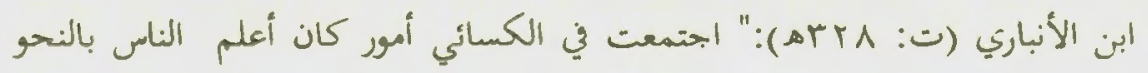

(1) حفص بن سليمان بن المغيرة الأسدي بالولاء، أبو عمر، ويعرف بحفيص: قارئ أهل الكوفة.

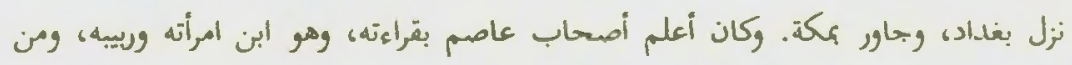

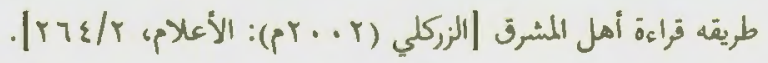

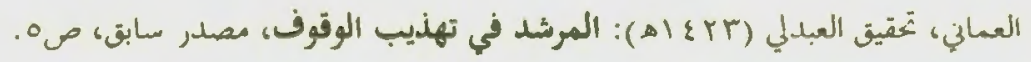

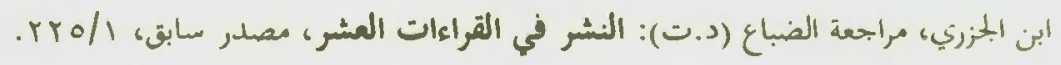

$$
-r V_{-}
$$


وواحلهم في الغريب وكان أوحد الناس في القرآن فكانوا يكثرون عليه حتى لا يضبط الأخذ عليهم فيجمعهم ويجلس على كرسي ويتلو القرآن من أوله إلى آخره وهم يسمعون ويضبطون عنه حتى المقاطع والمباديء". (1)

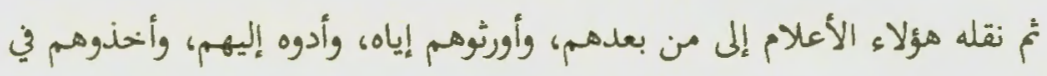
ذلك بالشدة والخزم لكيلا يضيع العلم .

قال محمد بن أحمد بن أيوب -يُعرف بابن شنبوذ-(ت:r يعقوب بن إسحاق الحضرمي إمام أهل البصرة في عصره في القراءات، وكان يأخذ

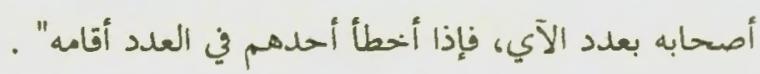
قال ابن شَنَبُوذ:"حدئني بذلك أحمد بن محمد بن شيبة العطار البصري قال:

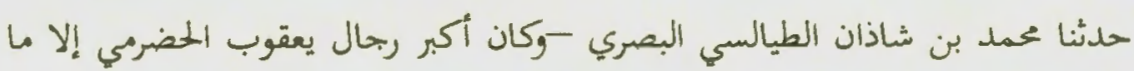

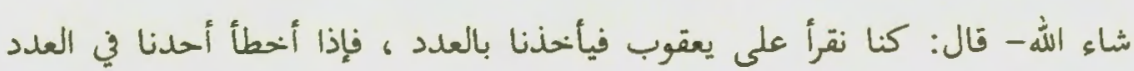
(أقامه" (r) ومضى هان العمل مسترملا جيلاً عن جيل عملو الأعصار والأمصار؛ ويتناقله الخلف عن السلف، ويأخذونه حرفاً حرفاً، وكلمةً كلمةً، وآيةً وآيةًة، إلى القرن التاسع -

الذهيي، محسد بن أحمد بن عثمان بن قايملاز الذهي،مسرفة القراء الكبار على الطبقات

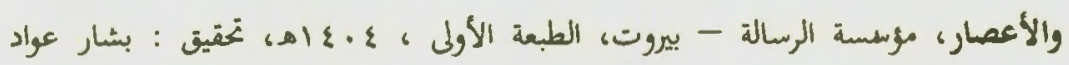

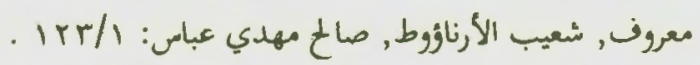

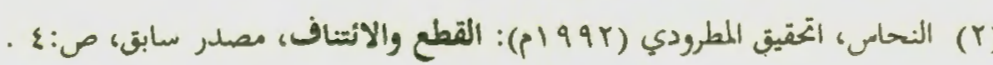


قال ابن الجزري:" وكان أئمتنا يوقفوننا عند كل حرف، ويشيرون إلينا فيه

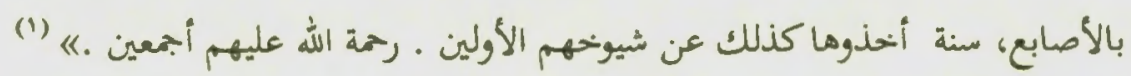
وهذا الذي دكره الإمام ابن المزري مسلكُ حسنّ، جرى به عمل المشُيخة من القرن الثاني الفجري إلى عصر الحافظ ابن المزري (القرن التاسع المجحري) . وبقي هذا العمل مسترسلكً جيلاً عن جيل إلى يومنا هذا، إلا أنه تقلص في بعض ديار الإسلام، وبقي وارف الظلال يُ بعضها، فكان القرأة يلقنون الآخذين عنهم المقاطع والمبادي، ويأحذوفهم بالحزم في ذلك، فمن فرَّط من الدارسين أو تقاون حتبوا عنه الإجازة، ولم يأذنوا له بالتصدر والإقراء . قال ابن المجزري: ومن هنا الشترط كثير من أنمة الخلف على المجيز أن لا بيجيز

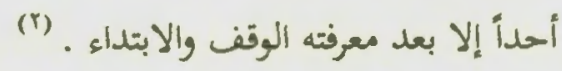
قال أبو جعغرٍ النحاس: "وقد تأول بعضُ العلماء حديثُ جرير بن عبد الله البجلي -رضي الله عنه-: [بايعنا رسول الله -صلى الله عليه ومسلم- على النصح لكل مسلم|"(r)، أنه ينبغي أن ينصح مَن علم القرآن، فيوقف الذي يعلمه على لـ يكتاج إليه

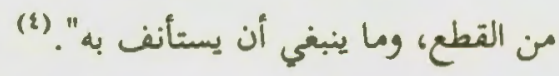

(1) ابن المزري، مراجعة الضباع (د.ت): النشر في القراءات المشر: مصدر سابق، rro/1.

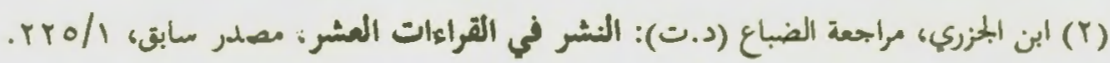
(r) رواه الشيخان.

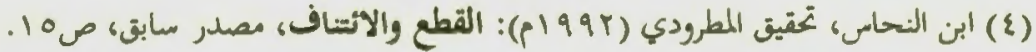


وحقيقُ على الشيخ وخليقٌ به أن يوقف الآنذذ عنه في بادئ أمره على المقاطع

والمبادي؛ حتى يشتّدَ عوده،وتصير له ملكة يكيز بما الصواب من غيره، لفلا يصلر منه ما لا ينبغي. والالا تاون الناس ووقعوا في المحظور بسبب فساد اللسان، وإن لم يقعوا فيه فسيكون أحسن أحوالمم حينعلٍ أن تمنفى عليهم معالم الجمال ومعاني الكمال في آي

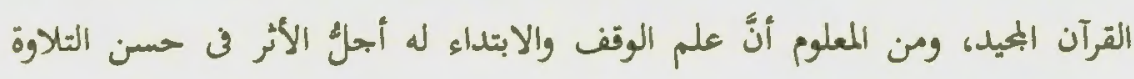
وجمال القراءة وجودة الأداء .

\section{المرحلة الرابعة: مرحلة التأليف:}

استمر السلف الصالح من الصحابة والتابعين يتناقلون مسائل هذا العلم مشافهة

إلى أن جاء عصر التدوين، فبدأ العلماء بالتأليف فيه، شأنه شأن مائر العلوم، وأول من عُلم أنه ألف في الوقف والابتداء: شيه بين نصاح المدني الكوفي (• rاهـ)، قال

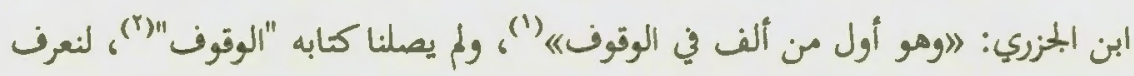
كيف كان منهج التأليف فيه، أو المادة التي كانت منطلقاً في هذا المضمار .

ومما يلفت الانتباه، أن كل من ألف في الوقف والابتداء كانوا من القراء

والنحويين، وقلَّ أن بحد إماهاً في القراءة أو اللغة إلا وله مشاركة في التصنيف في هذا العلم، ونذكر من القراء الذين لهم مشاركة في هذا الفن: ضرار بن صرد المقرئ الكوي

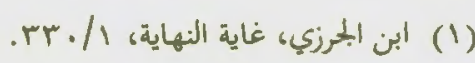

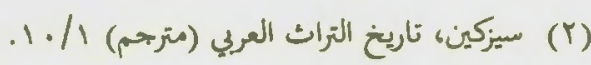

$$
\begin{aligned}
& -\varepsilon \cdot-
\end{aligned}
$$


ومن النحويين، الرؤاسي (') أبو جعفر محمد بن أبي سارة، أستاذ الكسائي والفراء

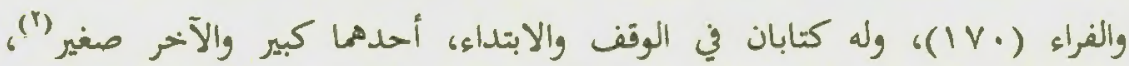

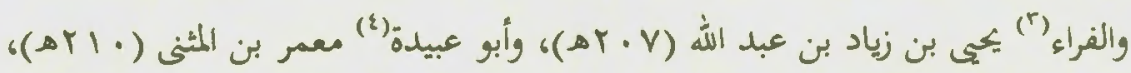

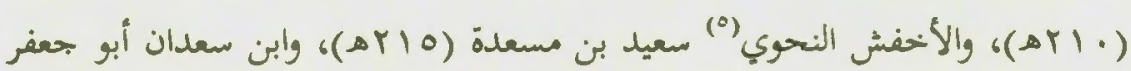

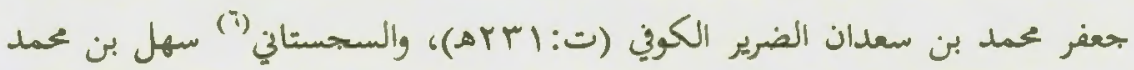

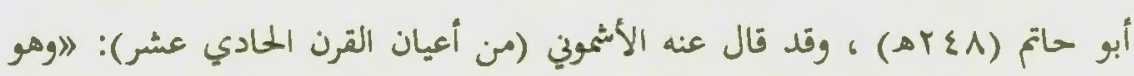

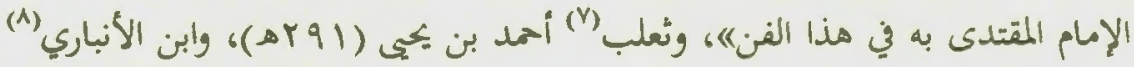

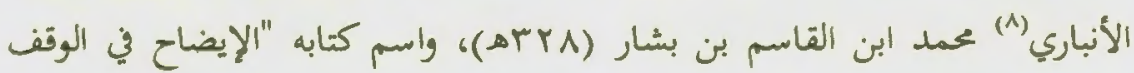

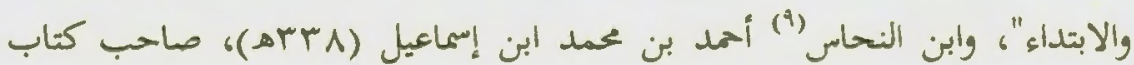
"القطع والايتناف".

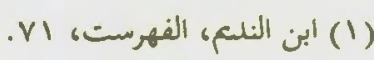

$$
\begin{aligned}
& \text { r (r) البغدادي، هداية العارفين، }
\end{aligned}
$$

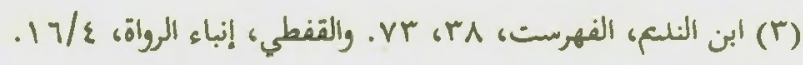

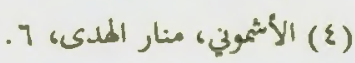

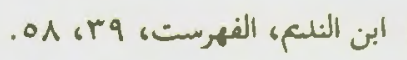

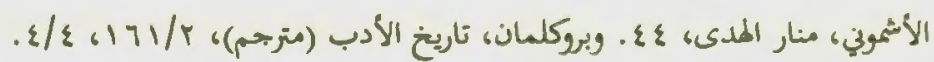

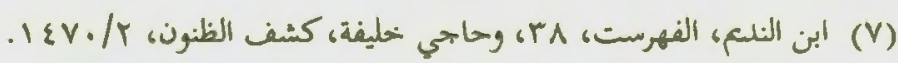

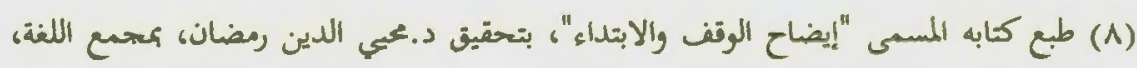

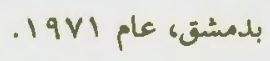

(9) طبع كتابه المسمى "القطع والاتثناف"، بتحقيق د.أحمد خطاب العمر، بوزارة الأوقاف العراقية،

$$
\text { عام 19v1 }
$$




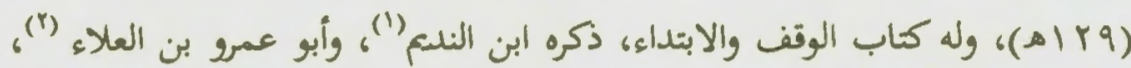

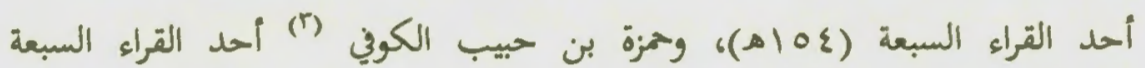

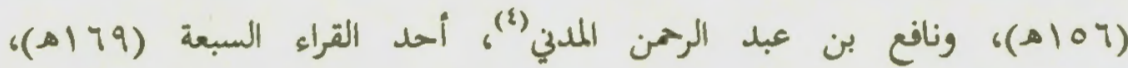

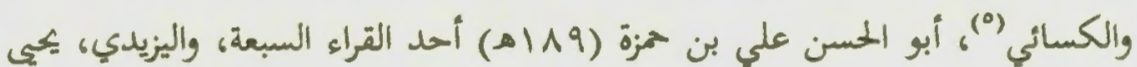

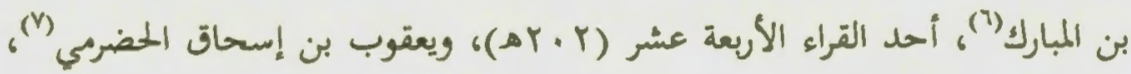

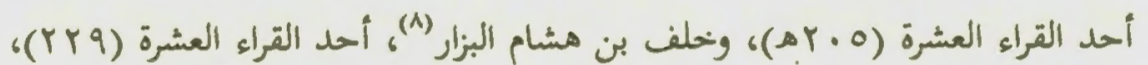
وحفص بن عمر بن عبد العزيز الدوري(")، المقرئ البغدادي الراوي عن الكسائي وأبي

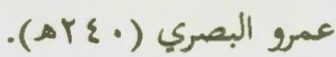

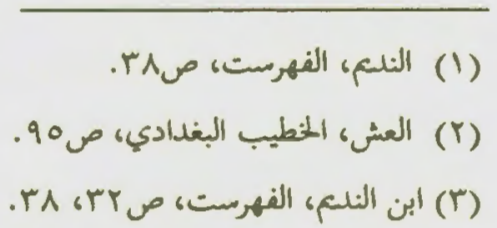

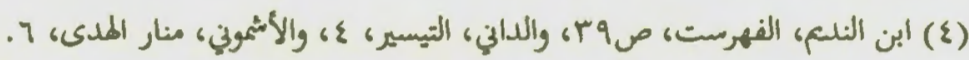

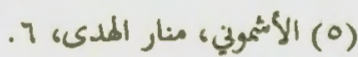

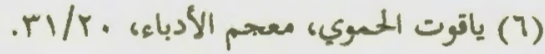

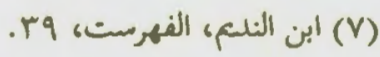

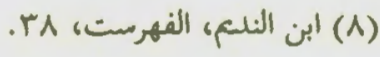

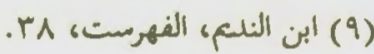


وأقدم ما وصلنا من هذه الكتب: كتاب ابن سعدان، وابن الأنباري، وابن

(1) (النحاس

ولم يكد ينتهي القرن الرابع المجري إلا وقد صنف أعلامنا في الوقف والابتداء

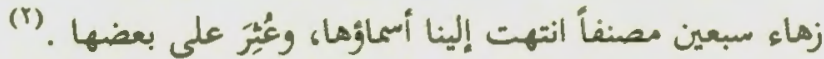

وئ هذه الفترة بدأ العلماء باستخدام مصطلحات الوقف؛ كالتام والكافي والحسن والقبيح ، وذكروها في كلامهم، وأكثروا من ذكرها. إلا أفا كانت في بادئ أمرها لم تكن قد انضبطت وعرف معناها على وجه التحديد بعد .

فمن العلماء المتقدمين في هذا الفن من أمتخلم جلة من المصطلحات في

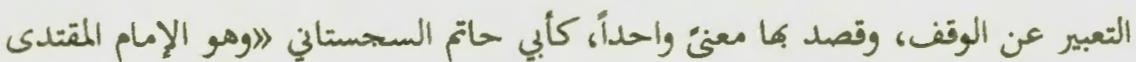
به في هذا الفنها، فقد ذكر عنه أبو محمد المماني أنه استعمل في كتابه ألقاباً كالتام والحسن والكافي والصالح والمفهوم، ولم يجبل كل لقبّ منها مقصوراً على معنيٌ بعينه، كما هو الحال اليوم، ولكنه قصد بسائر الألقاب معنئ واحداً، وهو أن الوقف يصلح

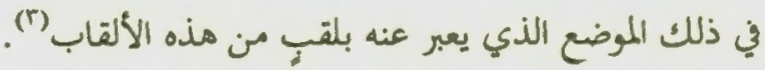

(1) انظر: مقدمة المحقق لكتاب المككفى للداني: 1 (1)

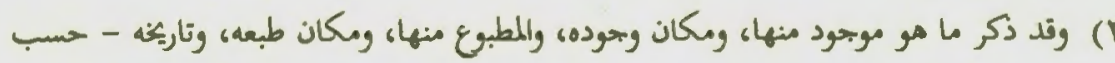

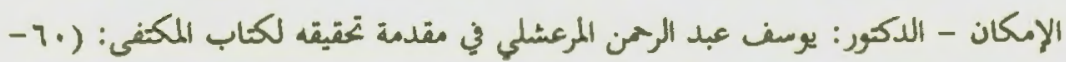
(V) ، والدكور عبد الكرعم بن محمد العثطان في مقدمة تحقيق الوقف والابتداء للغزال: .

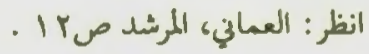




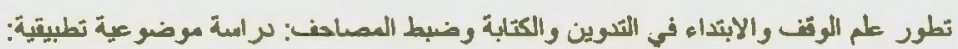

ثُّ علق العَمَّاني على مثل مذا الصنيع قائلاً: "فقد جعل الوقوف كلها باباً واحداً،

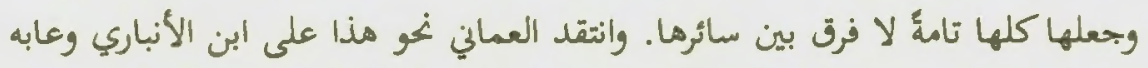
عليه، وذكر أنه بصنيعه هذا يكون مخالفاً لأهل هذه الصنعة فيما يختارونه، وليس يُمرُضِ، لأن تعاقب العبارة في التسمية لمسميً واحدٍ مما يوقع اللبس.

ثم ذكر أن القوم قصدوا بهذه العبارات الفرق بين درجات الوقف ومنازها في

المعنى، فوجب أن تدل هذه العبارات على منازلما ودرجاتما لتوافق أغراضهم" (1) وهذا شأن سائر العلوم في بداياتحا، يللي كل بأحسنِ ما عنده، ثم يتواطئ مائرهم بعدُ على أحسنِ المصطلحات، وأبينِ الألقاب، وأوضح العبارات.

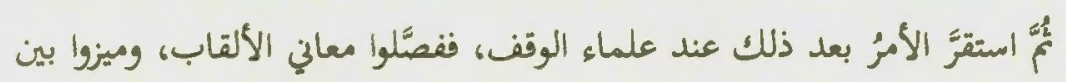
المصطلحات، وبيَُّوها، وباينوا بينها، وجعلوا لكل مصطلح معنئ مستقلاً ينفرد به عن غيره، ويتميز به عما سواه، -وإن كان قد جرى بينهم خحلاف يسير في ذلك- على

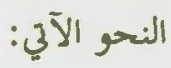

\section{ألمسام الموتف والإبتداء :}

قال الأسموني:" والناس في اصطلاح مراتبه مختلفون، كل واحدٍ له اصطلاح على

$$
\text { ما شاء، كما صرح بذلك صدر الشريعة، وناهيك به" (r). }
$$

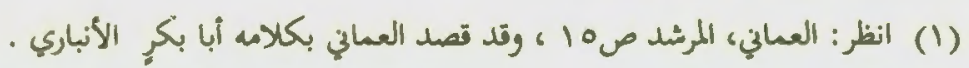

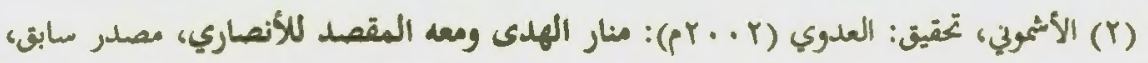
ص ص. 
وقال الحافظ ابن الجزري: "وقد اصطلح الأئمة لأنواع أقسام الوقف والابتداء

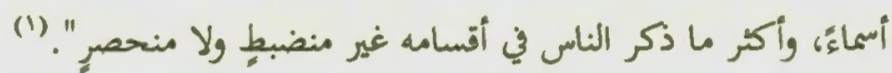

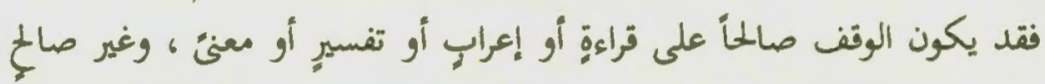

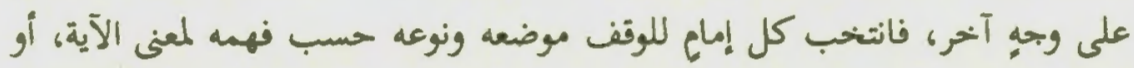

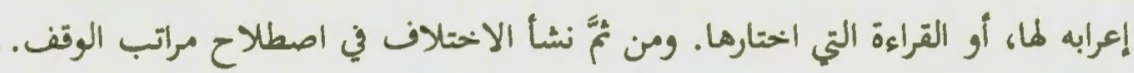

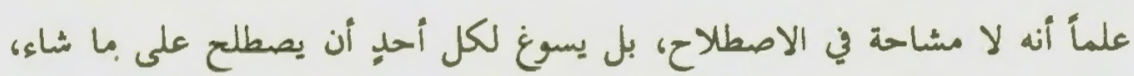

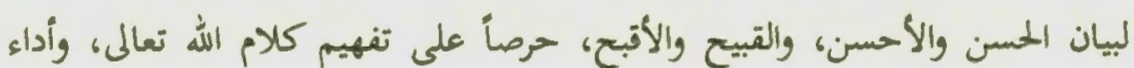
تلاوته على أتم وجه. (r)

فقي أول الأمر جعل بعض العلماء ومنهم ابن سعدان الكوفي الضرير (ت: إYM) مراتب الوقف و مصطلحاته على قسمين:

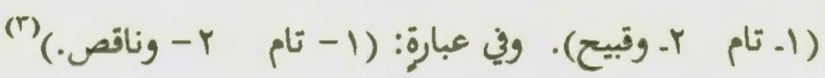
ثماء جاء ابن الأنباري فزاد قسماً ثالثاً:

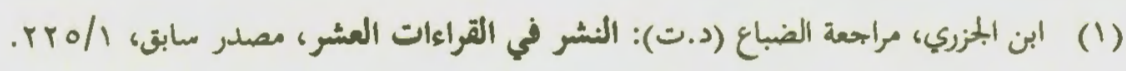

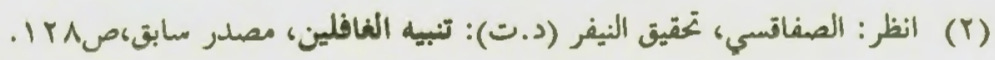

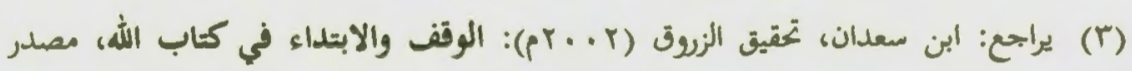

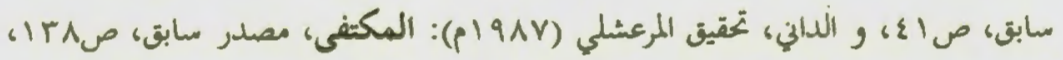

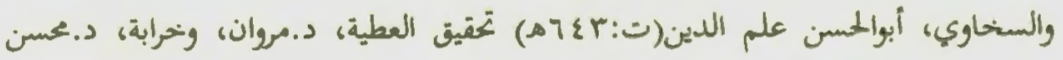

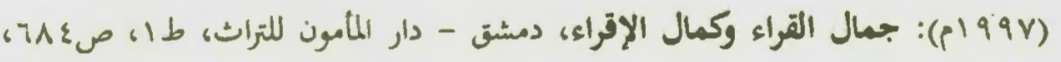

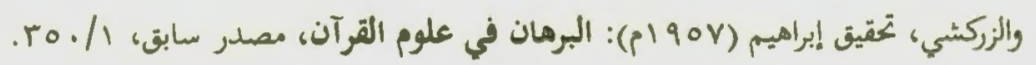


تطور عم الوتف والابتداء في التمرين والكتابة وضبط المصاحف: دراسة موضور مية تطبيقية:

(1-تام r- وحسن r- وقبيح). (1). ووافقه جماعة علي هiا الثثليث، مع

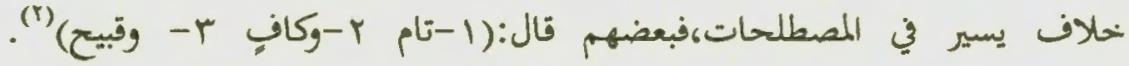

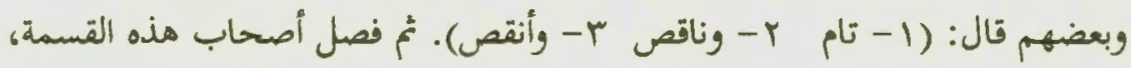
فجعلوها كالتالي:(1 الأتم ب r- والتام r- ب- والذي يشبه التام ع - والناقص المطلق

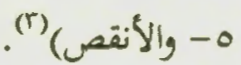

وقد تقدم مذا العلم عند المتأخرين، وتنقل أطواراً، واستقرّ على ما هو أدق من

هذا التقسيم (£)

فقل جاء بعلهم الحافظ أبو عمرو اللاني في القرن الملامس الهجري فحعلها أربعة أقسام، كالتالي: (1- تام ب r- وكاف ب- وحسن ع وقبيح). وتبعه على هذا السخاوي(Tـ Tهـ)، وابن المزري (0) وغيرهم.

$$
\begin{aligned}
& \text {.189/1: (1) }
\end{aligned}
$$

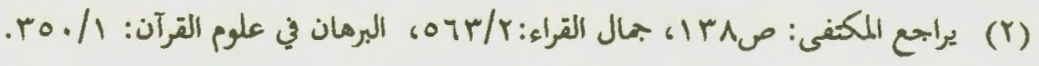

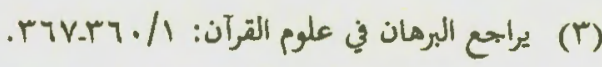

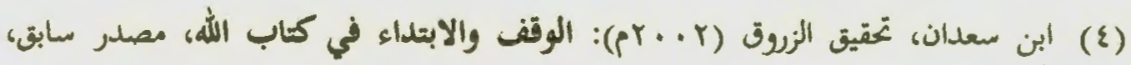

المقدمة ص الع.

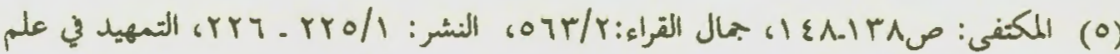

التجويد:ص170 
وخحالف في ذلك بعض الأئمة كأبي محمد العماني فجعلها خمس درجات،

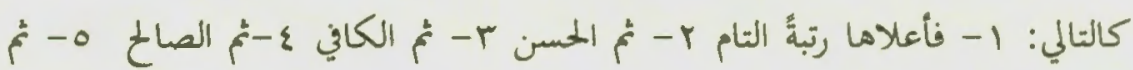

وأما أبو القاسم المذلي فقد صيرها ست مراتب: (1- وقف التمام بـ والحسن

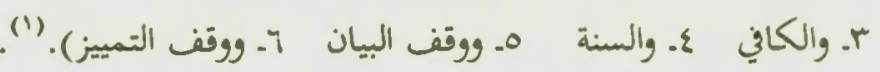

ووافقه أبو عبد الله السماوندي في العدد؛ لكن بطريقةٍ أخحى، فقد جعلها

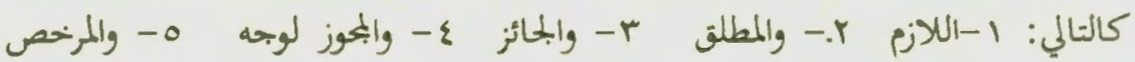

$$
\text { ضرورة †- وما لا يجوز الوقف - أو مالا وقف عليه). }
$$

ورمز لهذه الأقسام الستة بعلامات: فرمز للازم بحرف (م)، وللمطلق بكرف

(ط)، وللحائز بحرف (ج)، والمحوز لوجه بكرف (ز)، والمرخص لضرورة بحرف (ص)،

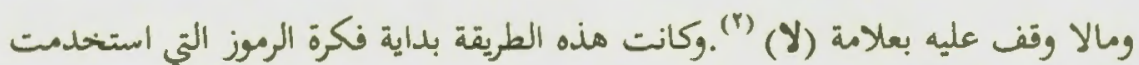

في كتابة المصاحف بعد ذلك .

$$
\text { مُم تلاهم أقوام زادوا في تقسيم الوقف ، فتعلوه على ثمانية أضرب: (1 تام }
$$

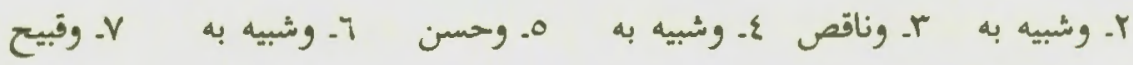

1ـ ومبيه به).

$$
\begin{aligned}
& \text { (1) الوقف والابتداء للهذلي: صـ4r. . . ع . } \\
& \text { علل الوقوف:1/1 ـ ـ 1ـ } 179
\end{aligned}
$$




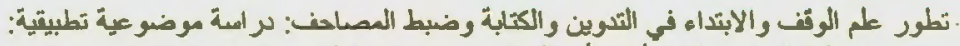

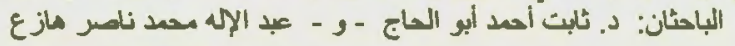

وهذا القول نسبه الزركشي(ع وله) للجمهور (1). ونسبه للجمهور أيضاً من

قبله أبو الكرم المبارك بن فاخو النحوي (ت:0.0هـ) دكر ذلك عنه السخاوي") (r).

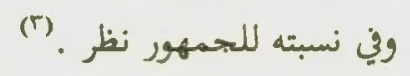

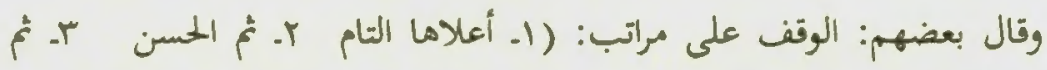

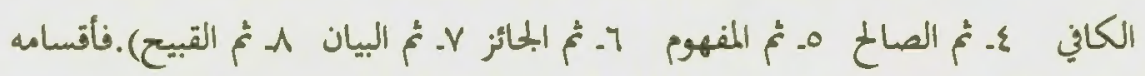

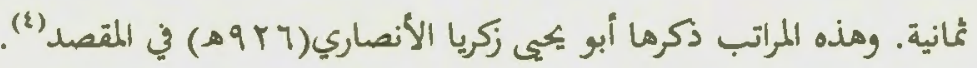

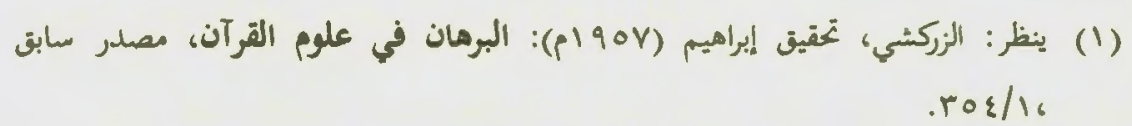

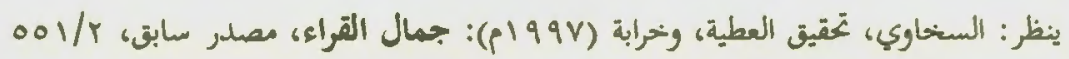
$.00 Y-$ لما تقدم أنَّ رأي جاهير السلف والملف يقضي بخلاف هذا ـ انظر: ابن النحاس، تمقيق المطرودي (Y99 ام): القطع والأيتناف، مصدر سايق، صا، الداني، تمقيق المرعشلي

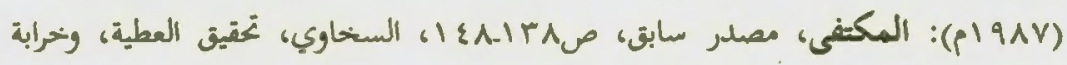

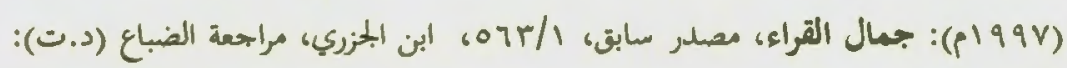

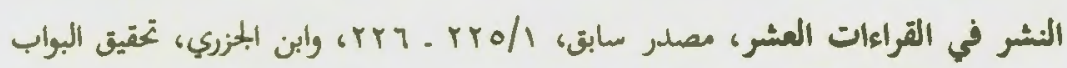
(910 ام): التمهيد في علم التجويد، مصدر سابق، ص م7 أ أ، المرصفي (د.ت): هلداية

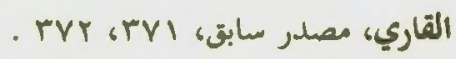

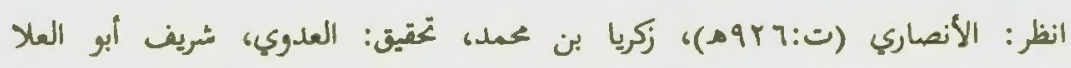

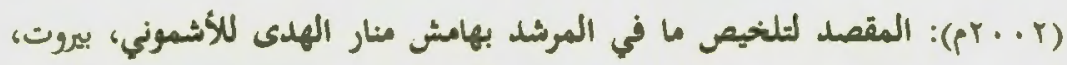

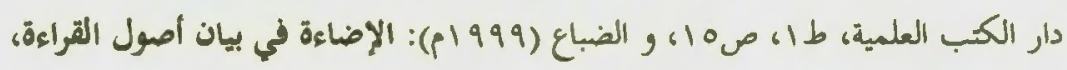

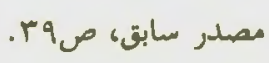


وبعضهم جعله ثُمانية أضرب، لكن بطريقة أخرى كالتالي: ( اـ كامل ب. تام

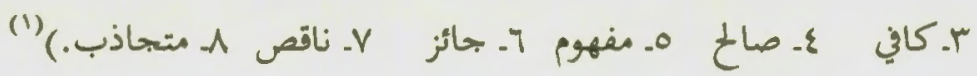

وأما أبو الحسن الصفاقسي فقد وافقهم في العدد، إلا أنه اختار تقسيم الداجي،

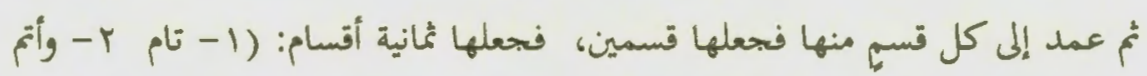

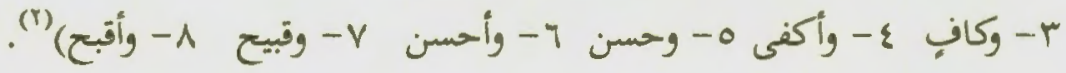

ووافقه في طريقته الأمثوني (3ي القرن الحادي عشر الهجري)، فعمد إلى من قسم

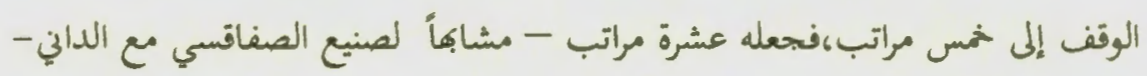

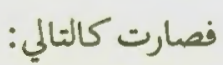

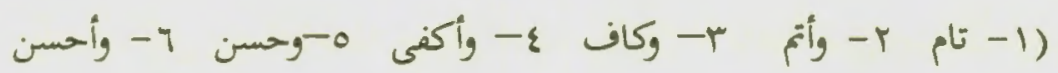

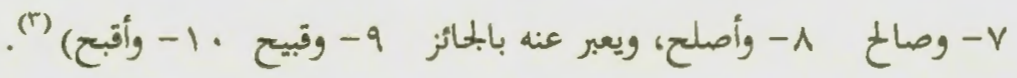

وجاء الشيخ حكيم زاده (في القرن الحادي عشر الهجري) فزادها إلى أحد عشر

قسمهاً، وجعل لكل قسم من الأتسام رمزاً يعرف به، واستفاد ذلك من تقسيمات السجاوندي ورموزه وتطبيقاته للرموز في مواضع القرآن، وأضاف إلى ذلك أقسام ورموز أشحىى، ونظمها في منظومته (مبادئ معرفة الوقون). فذكر الستة الأقسام التي دكرها السماوندي مع رموزها ، ثم دكر بعد ذلك خمسة أقسام أخرى، وهي:

(1) يراجع: تنبيه الغافلين وإرشاد البلاهلين: ص 71.

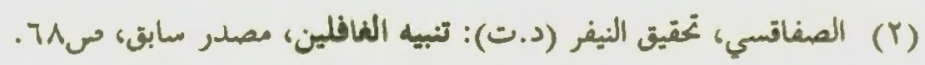

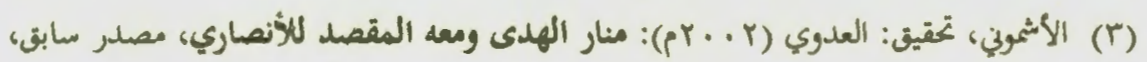

ص.1. 


$$
\text { هـ الوقف الملهق بـ الوصل، ولكن قد قيل فيه: الوقف أيضاً، ورمز له بـ (ق). }
$$

9. ما هو عكس الوقف الملحق بالوقف المطلق، أي: ما لا وقف عليه: ورمز له بـ

• اـ ماكان الوقف عليه جائزاً، لكن الوصل أولى من الوقف، ورمز له بـ (ِلِي).

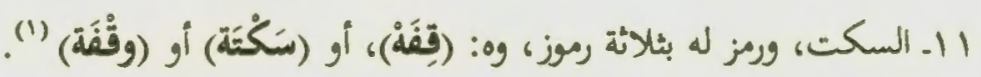

وخحلاصة الكلام أن علماء هذا الفن -رحهم الله تعالى - قل اختلفوا في أقسابه

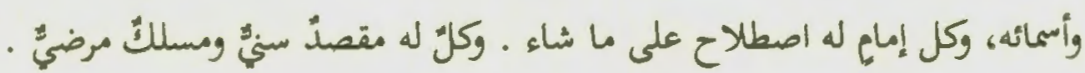

بَيَد أنَّ الأمر استقر عند مُلو المتأخرين فاصطلحوا - تبعاً لإمام الفن وشيخ الصنعة ابن المزري- على أنه أربعة أقسام: تام مختار، وكاف صالح، وحسن مفهوم،

$$
\text { وقيتح متروك. }
$$

\section{المرحلة الخحامسة: القرن السادس الهجري وما بعده:}

مضى القول بأن السِحاوندي (ت: • 70هـ) في القرن السادس الهمري بنى كتابه في الوقوف على طريقة الرموز، فرمز للوقف اللازم بكرف (م)، وللمطلق بحرف (ط)، وللجائز بحرف (ج)، والمجوز لوجه بحرف (ز)، والمرخص لضرورة بحرف (ص)، ومالا 
وقف عليه بعلامة (لا) (1). وكانت هذه الطريقة بداية فكرة الرموز التي استخلمت في كتابة المصاحف بعد ذلك كما أمسلفنا .

ثم تلاه الشيخ حكيم زاده في القرن الحلادي عشر الهجري فزادها إلى أحد عشر قسماً، وجعل لكل قسم من الأقسام رمزاً يعرف به، واستفاد ذلك من تقسيمات السجاوندي ورموزه وتطبيقاته للرموز في مواضع القرآن، وأضاف إلى ذلك أقسام ورموز أخرى، ونظمها في منظومته:(مبادئ معرفة الوقوف). فذكر الستة الأقسام التي ذكرها السماوندي مع رموزهائم ذكر بعد ذلك خمسة أقسام أخرى، وهي: V. ما فيه الوصل، ولكن قد قيل فيه: الوقف أيضاً، ورمز له بـ (ت). 1ـ الوقف الملحق بـ (الوقف المطلق ) ورمز له بـ (قِفن ).

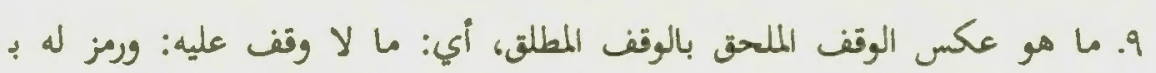

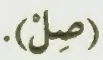

• 1ـ ماكان الوقف عليه جائزاً، لكن الوصل أولى من الوقف، ورمز له بـ (صِلِي).

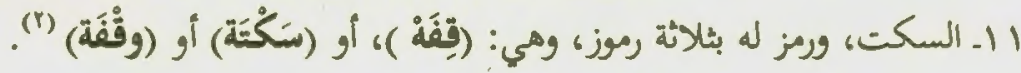

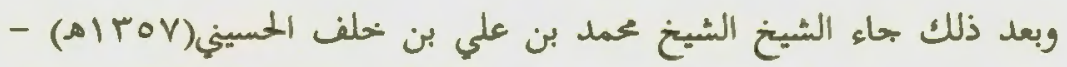

شيخ عموم القراء والمقارئ بالديار المصرية في وقته- فهعل الوقف على شمس مراتب: 1- (لازم ): وهو ما قد يوهم نحلاف المراد إذا وصل بما بعده . 


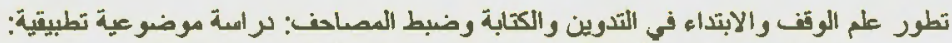

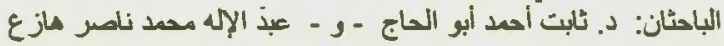

Y- (وجائز مع كون الوقف أولى): وهو الذي لا يتعلق بشي مما بعده لا من جهة

اللفظ ولا من جهة المعنى (1)

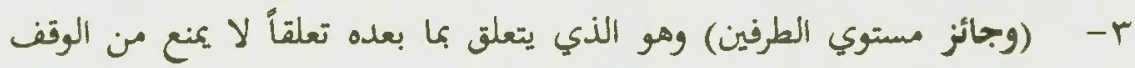

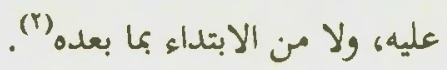

ع - (وجائز مع كون الوصل أولى) وهو الذي يتعلق بما بعده تعلقاً لا يمنع من

$$
\text { الوقف عليه، وركن يمنع من حسن الابتداء بما بعده (r). }
$$

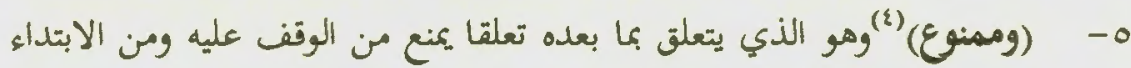

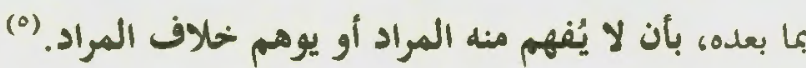

واعتُبد نو هذا في المصحف المصري في بعض طبعاته؛ حيث كان الشيخ

الحسيني مشرفاً ومراقباً على طباعة المصحف، وحذا أعضلاء لجان مراقبة المصاحف حذوه مع بعض الملالاف، وكان من أشهرها طبعتي مصحف المدينة الأولى والثانية. على ملى مرافيه امتدراك على بعض مواطن الوقف ورموزه في الطبعة الثانية .

$$
\text { وهذا هو الذي يقابل التام عند ابن الجزري ومن معه . }
$$

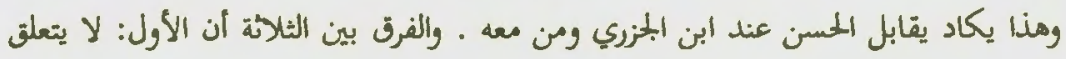
يما بعده أصلاً، والثاني: يتعلق بما بعده من جهة المعنى فقط، والثالث: يتعلق ما بعده به به تعلقاً كمع من حسن الوقف عليه والابتداء يما بعده.

$$
\begin{aligned}
& \text { وهذا هو الذي يقابل القبيح عند ابن الجزري ومن معه . }
\end{aligned}
$$

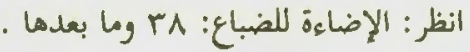


وبقي الحال في المصاحف المغربية على ما كان عليه من الالتزام بتقييدات الهبطي

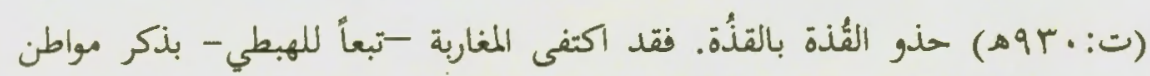

الوقف في مصاحفهم، مع إغفال مراتبها وأنواءها.

فقد جعلوا الوقوف كلها في مرتبة واحدة، وأشاروا إلى كل موطن يصح فيه

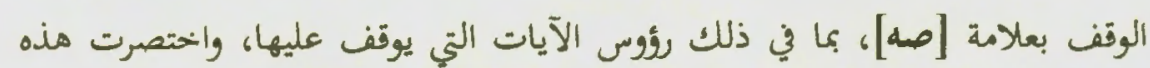

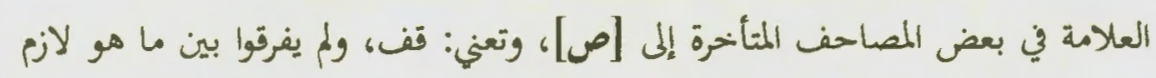

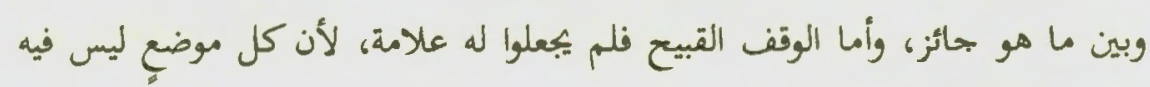

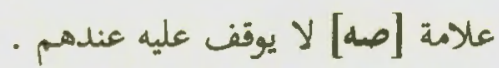

وأما في شبه القارة المندية فقد كان الاعتماد في المصاحف عندهم على المات اختيارات السجاوندي في كتابه [علل الوقوف] . وبقي الحمال على ما هو عليه إلى يومنا . is

\section{的橎}


تطور علم الوقف والابتداء في التدوين والكتابة وضبط المصاحف: درامة موضو عية تطبيقية:

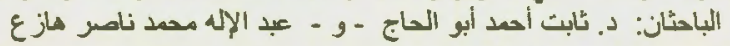

المبحت الثالت

الإراسة التطبيقية: جداول توضيحيّة للوقف والابتداء

مواضعها وعلاماتها في الصفحات الأولى من القرآن الكريم

المطب الأول - الم

جدول المقارنة بين المصاحف في المقاطع والمبادي

سبوة الفاتحة:

\begin{tabular}{|c|c|c|c|c|c|c|c|c|c|c|c|c|}
\hline $\begin{array}{l}-1 \\
3 \\
3\end{array}$ & $\begin{array}{l}3 \\
3 \\
-1\end{array}$ & $\frac{j}{\frac{3}{3}}$ & 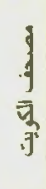 & $\begin{array}{l}3 \\
7 \\
7 \\
7 \\
2\end{array}$ & $\begin{array}{l}j \\
3 \\
3 \\
= \\
=\end{array}$ & $\begin{array}{l}j \\
\frac{j}{3} \\
=3 \\
+\frac{1}{3}\end{array}$ & $\begin{array}{l}1 \\
y \\
-3 \\
-3\end{array}$ & $\begin{array}{l}j \\
\frac{j}{3} \\
\frac{3}{7} \\
\frac{3}{7}\end{array}$ & 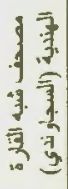 & $\begin{array}{l}\frac{8}{3} \\
\frac{3}{3} \\
\frac{3}{3}\end{array}$ & 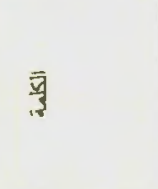 & $\sqrt{3}$ \\
\hline \multirow{6}{*}{ 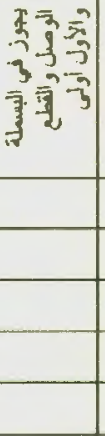 } & - & - & - & - & - & - & - & - & - & - & (الرحبي ) ) & , \\
\hline & - & - & - & - & - & - & - & - & $y$ & - & 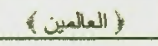 & $r$ \\
\hline & - & - & - & - & - & - & - & - & $y$ & - & (الرحِيم) & $r$ \\
\hline & - & - & - & . & - & - & - & - & $b$ & مس & (الدين ) & $\varepsilon$ \\
\hline & - & - & - & - & - & - & - & - & b & صـ & ( تصنسين ) & 0 \\
\hline & - & - & - & - & - & - & - & - & $y$ & - & () & 7 \\
\hline \multirow{2}{*}{ 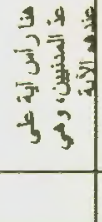 } & - & - & - & - & - & - & - & - & $y$ & - & ( أنعت عيهر ) & $r$ \\
\hline & . & . & - & - & - & - & - & ${ }^{-}$ & - & صه & (ولا الضلبن) & $r$ \\
\hline
\end{tabular}


سيونة البقة:ة

\begin{tabular}{|c|c|c|c|c|c|c|c|c|c|c|c|c|}
\hline $\begin{array}{l}1 \\
3\end{array}$ & $\begin{array}{l}3 \\
3 \\
3\end{array}$ & $\begin{array}{l}3 \\
\frac{j}{2} \\
\frac{3}{3} \\
\frac{3}{3}\end{array}$ & $\begin{array}{l}3 \\
3 \\
3 \\
3\end{array}$ & $\begin{array}{l}1 \\
-3 \\
\overline{3} \\
7 \\
-1 \\
2\end{array}$ & $\begin{array}{l}j \\
3 \\
.3 \\
1 \\
1\end{array}$ & 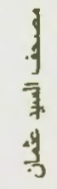 & $\begin{array}{l}\frac{3}{3} \\
\frac{3}{3} \\
3\end{array}$ & $\begin{array}{l}3 \\
j \\
\overline{3} \\
\frac{7}{7} \\
\frac{3}{7}\end{array}$ & 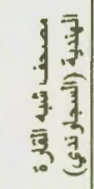 & $\begin{array}{l}3 \\
\overline{3} \\
-3 \\
3\end{array}$ & 牙 & $\overline{7}$ \\
\hline & - & - & - & - & - & - & - & - & $\varepsilon$ & مس & (ل) & , \\
\hline & $\therefore$ & $\therefore$ & $\therefore$ & $\therefore$ & $\therefore$ & $\therefore$ & $\therefore$ & $\therefore$ & ملم؛ & as & (لاريب) & $r$ \\
\hline & $\therefore$ & $\therefore$ & $\therefore$ & $\therefore$ & $\therefore$ & $\therefore$ & $\therefore$ & $\therefore$ & $e^{6} \therefore$ & - & (فيه) & $r$ \\
\hline & - & - & - & - & - & - & - & - & $y$ & - & (المتسين ) & $r$ \\
\hline & - & - & - & - & - & - & - & - & b & مله & (ينتون ) & $r$ \\
\hline & - & - & - & - & - & - & - & - & द & - & (s)lili) & $\varepsilon$ \\
\hline & - & - & - & - & - & - & - & - & b & - & (يوتلتون ) & $\varepsilon$ \\
\hline & ملي & صلي & ملي & ملي & ملى & ملي & ملي & ملى & ن & مي & (من ربه ) & 0 \\
\hline & - & - & - & - & - & - & - & - & - & مس & (الهفلحون ) & . \\
\hline & - & - & - & - & - & - & - & - & - & مמג & (يؤمنون ) & 8 \\
\hline & ملح & ملي & ملي & ملي & ملي & ملمي & ملى & ملي & $b$ & مدג & ( سمعهم ) & $\checkmark$ \\
\hline & ملي & مله & ملي & مله & مله & ملمى & ملي & ملى & j & مدג & (: ) & $r$ \\
\hline & - & - & - & - & . & - & - & - & - & مسג & (م)يم (م) & $v$ \\
\hline & - & $=$ & - & . & - & - & - & - & $s$ & مده & (بمؤمنين ) & $\wedge$ \\
\hline & - & - & - & - & . & - & - & - & $\varepsilon$ & مس & (1) & 9 \\
\hline & - & - & - & $=$ & - & - & - & - & $b$ & مe & ( بشسرون ( & 9 \\
\hline & - & - & - & - & - & - & . & - & $y$ & מa & (مرض ) & 1. \\
\hline & ملي & ملى & ملي & ملى & ملي & ملي & ملي & ملم & $\varepsilon$ & as & (مرضاً) & 1. \\
\hline & - & - & - & - & - & - & - & - & $y$ & - & (أليز ( ) & 1. \\
\hline
\end{tabular}


تطور علم الوتف والابتداء في التدوين والكتابة وضبط المصاحف: مراسة مرضو عية تطبيقة:

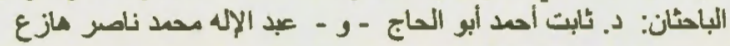

تئبع : سورة الثيقة:

\begin{tabular}{|c|c|c|c|c|c|c|c|c|c|c|c|c|}
\hline $\begin{array}{l}-1 \\
\text { 尚 }\end{array}$ & $\begin{array}{l}3 \\
3\end{array}$ & $\frac{1}{3} \frac{3}{3}$ & $\begin{array}{l}3 \\
\overline{3} \\
3\end{array}$ & $\begin{array}{l}3 \\
3 \\
3 \\
3 \\
-1 \\
-1 \\
2\end{array}$ & $\begin{array}{l}j \\
j \\
3 \\
3 \\
\pm\end{array}$ & $\begin{array}{l}j \\
3 \\
=3 \\
4 \\
=3\end{array}$ & $\begin{array}{l}j \\
3 \\
3 \\
3 \\
3\end{array}$ & $\begin{array}{l}j \\
j \\
\frac{3}{3} \\
\frac{7}{7}\end{array}$ & 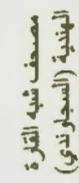 & $\begin{array}{l}3 \\
\frac{3}{3} \\
3 \\
3\end{array}$ & 武 & $\overline{7}$ \\
\hline & - & - & - & - & - & - & - & - & - & صه & ( بكنبون ) & 1. \\
\hline & - & - & - & - & - & - & - & - & $y$ & - & (الأرض ) & 11 \\
\hline & - & - & - & - & - & - & - & - & - & صه & (مصلحون (م) & 11 \\
\hline & - & - & - & - & - & - & - & - & - & صـ & (يشعرون) & ir \\
\hline & تلى & تلى & قلى & تلمي & تلى & تلىي & تلىي & تلبي & b & صه & (السفهاء) & ir \\
\hline & - & - & - & - & - & - & - & - & - & صه & (لا يطمون ) & ir \\
\hline & - & - & - & - & - & - & - & - & صله، & صه & (مأمنا (م) ) & 18 \\
\hline & - & - & - & - & - & - & $y$ & - & $y$ & - & (") & 18 \\
\hline & - & - & - & - & - & - & $y$ & - & $y$ & - & $(\operatorname{sen})$ & 18 \\
\hline & - & - & - & - & - & - & - & - & - & صه & ( مستهز هون ) & 18 \\
\hline & . & - & - & - & - & - & - & - & - & صه & ( يعسون ) & 10 \\
\hline & - & - & - & - & - & - & - & - & ص & - & (بالهاى ) & 18 \\
\hline & - & - & - & - & - & - & - & - & - & صه & (ميتدن ) & 14 \\
\hline
\end{tabular}




$$
\text { المطاب الثاني }
$$

جدول المقارنة يبيّن أقوال العماء وأرائهم في المقاطع والمبادي

سبورة انفاتهة:

\begin{tabular}{|c|c|c|c|c|c|c|c|c|c|c|c|c|}
\hline $\begin{array}{l}\text { 里 } \\
\text { 哥 }\end{array}$ & 象亨 & $\frac{\sqrt{1}}{3}$ & $\frac{\bar{x}}{3}$ & $\frac{\overline{3}}{3}$ & 紊 & $\overline{3}$ & $\frac{3}{3}$ & $\frac{\overline{7}}{3}$ & $\frac{\overline{3}}{3}$ & $\frac{5}{3}$ & 予 & 咨 \\
\hline 牙衰 & & تمث & أتم & تلمّ & وتغ & تالم & تام & أثئَ & تصام & تلم & (الرسيم) ) & ' \\
\hline & & جاتز & 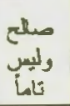 & & وتن لا & & صلح & حسن & & وليسن & (البالعيز ) & $r$ \\
\hline & & جاتز & كاكتبِ & & وت & & كاب & حسن & & وليسل & ( الرحير ) & $r$ \\
\hline 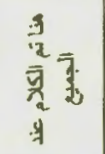 & تـ & تائ & تام & & مطلت & & حسن & تام & تَمام & تام & ( السين ) & $\xi$ \\
\hline $\begin{array}{l}3 \\
3 \\
3 \\
3 \\
3\end{array}$ & تض & تَ" & تامر & & مطلتى & & تاّم & تזم & تلم & تلק & ( نستعزن) ) & 。 \\
\hline & & جدز & وانيسن & & وتن & & جتز & حسن & & وليس & ( (لالمستخيم ) ) & 9 \\
\hline & & هبز & والثهن & & وتن & & & 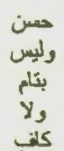 & & بتألم & (انسيه) & $v$ \\
\hline 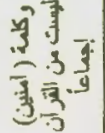 & مت & كانز & ن نز & & وقة & & " لمّ & تانز & تسلم & تلم & الضالين) & $v$ \\
\hline
\end{tabular}


تطور علم الوقف والابتداء في التدوين والكتابة وضبط المصاحف: ر استة موضو عية تطبيقية:

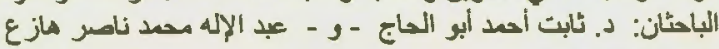

سبرة البيقرة:

\begin{tabular}{|c|c|c|c|c|c|c|c|c|c|c|c|c|}
\hline 聂 & 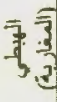 & $\frac{\sqrt{3}}{3}$ & $\frac{\overline{3}}{3}$ & $\frac{\sqrt[3]{3}}{3}$ & $\frac{1}{3}$ & $\begin{array}{l}\overline{7} \\
\overline{5}\end{array}$ & $\frac{3}{3}$ & $\frac{7}{3}$ & 可 & 霎 & 可 & $\overline{3}$ \\
\hline 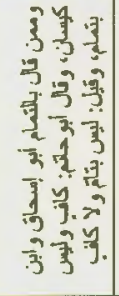 & كنف & 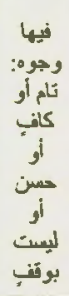 & تلئ أو & & جاتز & تام & تام & تام & تمام & 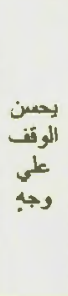 & (آل () & 1 \\
\hline ألم أنهاتئي & & وجى & طهى & ثنام & & لا يتم & هغهوم & & 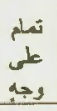 & تبيع & ( الكانب) & $r$ \\
\hline 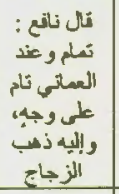 & تَت & كلن & وتى & & وجلى وجل & & التعلم & & وبى تصن & وبلى ورئ، & (لاريب ) & $r$ \\
\hline & & كَام أرهو: & كألم أُ & كلب & 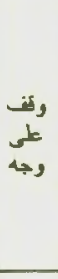 & عسن & تام & كلب & & الوتى & (4) & $r$ \\
\hline 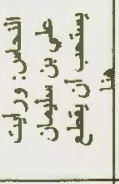 & & جلمن لرن & تلمز أو & كلت & 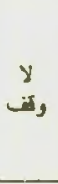 & & كلتب & كلن كن & تالم & ولئن & ( لمتشين ) ) & $r$ \\
\hline 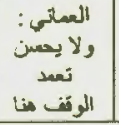 & & جتز & جتز & & & حسن & جتز & & & ولئام & (بالغيب) & $r$ \\
\hline
\end{tabular}




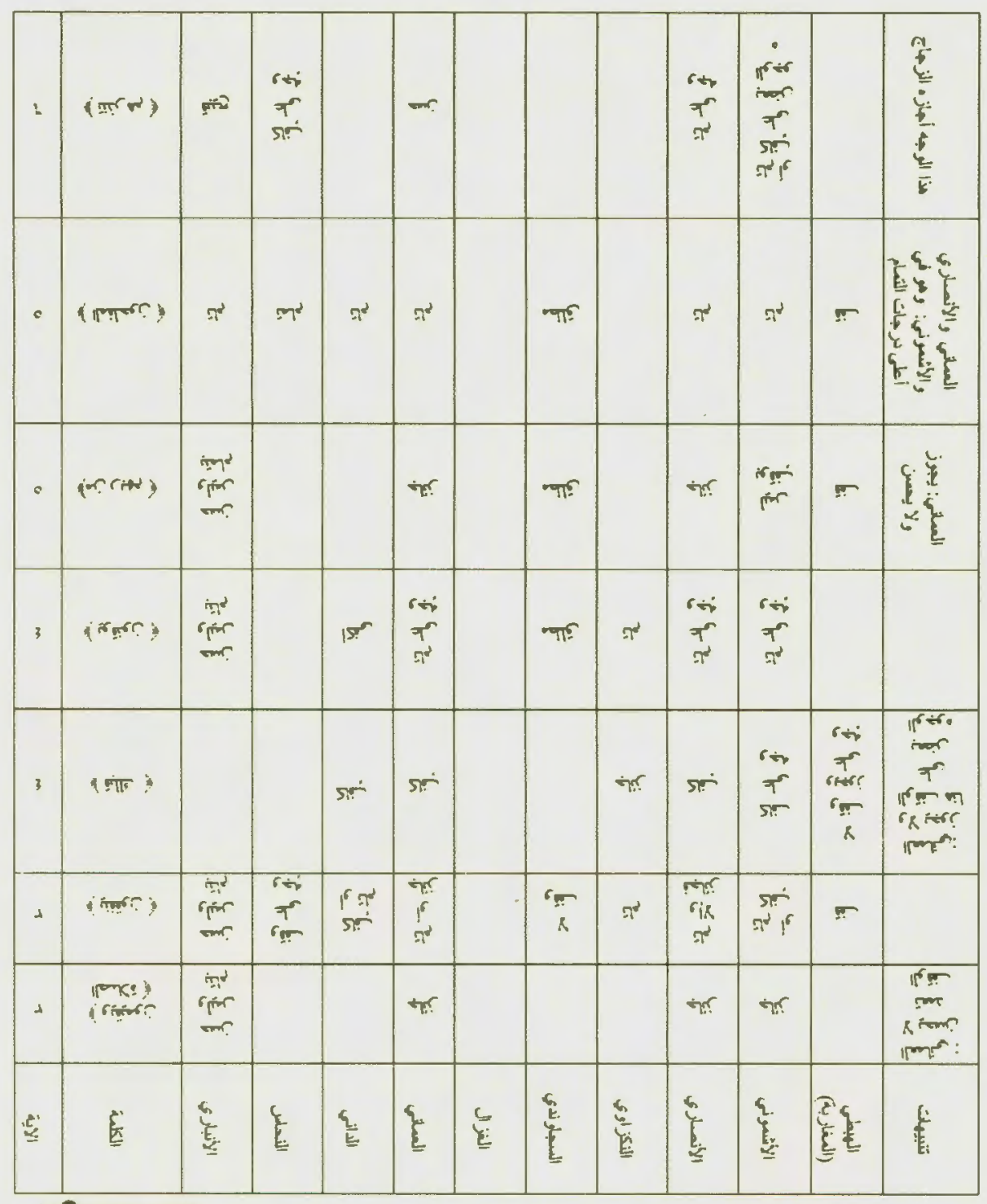

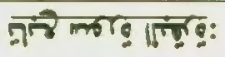


تطور عم اللوتف والابتداء في التُوين والكتابة وضبط الهصاحف: براسة موضر عية تطبيقية:

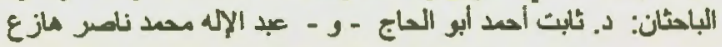

تابع سورة البيمرة:

\begin{tabular}{|c|c|c|c|c|c|c|c|c|c|c|c|c|}
\hline 泰 & 事亨 & $\frac{\overline{1}}{3}$ & $\frac{5}{3}$ & 司 & $\frac{1}{3}$ & $\frac{3}{5}$ & $\overline{3}$ & $\frac{5}{3}$ & $\frac{7}{3}$ & 交 & 可 & $\bar{s}$ \\
\hline 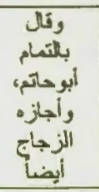 & & تن & تاتم & & مطلق & & تام & كلب & كان & حتئ ال & ( يؤمنون ) & 1 \\
\hline التأنش: & & وبلى & جلزز & & & & | جلز & & وتى وجن & 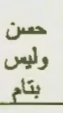 & ( تلوبه ) & v \\
\hline \multirow[t]{2}{*}{ 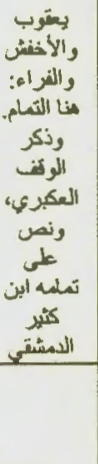 } & 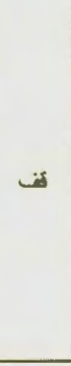 & وجلى & كالتز & & مطلق & & تالم & كلمئل & وقت & حسن & ( (سمه ) & v \\
\hline & تَ & حسن & مطاع & كلب & يجوز & حسن & مer & كلب & & حسن & (هنرة) & v \\
\hline \multirow{5}{*}{ 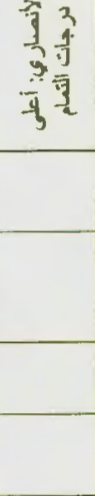 } & تَف & تأم & تمام & تمت & مطلق & تأم & ثنمّ & تَ"م & تصن & تحم & (عظلي ) ) & $\checkmark$ \\
\hline & & ر & & & & & & & كلف & & الأوبليوم) & $A$ \\
\hline & & 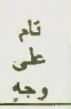 & ائلح & & لازم & & ترمتح & كافي & وكانب & وتلئ & ( بمومنزن ) ) & $A$ \\
\hline & تَ & حصن & تام & كنف & جتز & حسن & تام & كاث & كانب & صسن & (8) & 9 \\
\hline & & يجوز & 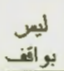 & & & & & كاتب & كاتب & حسن & (أنغهم ) & 9 \\
\hline
\end{tabular}




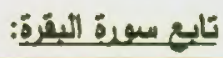

\begin{tabular}{|c|c|c|c|c|c|c|c|c|c|c|c|c|}
\hline 事 & 事亨 & $\frac{\overline{1}}{3}$ & $\frac{\overline{3}}{3}$ & $\frac{5}{3}$ & 章 & $\begin{array}{l}3 \\
5\end{array}$ & 3 & $\frac{\overline{7}}{3}$ & 3 & $\frac{5}{3}$ & 可 & 秀 \\
\hline أبوهاتم & تث & كلف & كانب & Sas & سطلق & كاف & Sals & اكلى & تملم & سمن & (ئinرون) & 9 \\
\hline \multirow[t]{3}{*}{ الألأل الثموني } & تت & صلع & صطع & كاتب & وت ل & عسن & صلح & كلف & كان & عسن & (مرض) & 1. \\
\hline & ثن & كلب & مec & كاف & جانز & حسن & ع. & أكني & تملم & عمن & (ing ) & 1. \\
\hline & & ليوائت & & & & رئ لy & & علي تُ & لوكت لئ & تيجيع & (ili) & 1. \\
\hline \multirow[t]{2}{*}{ 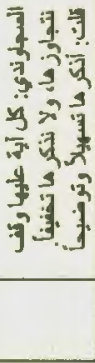 } & ت & كلف & ثلم & كلب & مطلق & & تهم & كالي كاب & صسن & سمن & (يكنبون ) & 1. \\
\hline & & y & & & $\begin{array}{l}y \\
\text { g. }\end{array}$ & & & & بكلب & & (الأرض) & $" 1$ \\
\hline \multirow[t]{2}{*}{ اليوعت3 } & تن & كتب & كاتب & مغهرe & مطلت & كتب & ST & كالب & كانب & حسن & (مصلحون ) ) & $" 1$ \\
\hline & & بوأتي & بوائتي & & مطلق & & & & & مسن & (المفسدون ) & ir \\
\hline 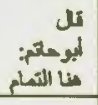 & تה & كa & كلة & Sas & مطلق & كה & تائ & كالت & تملم & مسن & ( ئسرون ) & ir \\
\hline \multirow[t]{2}{*}{ كايو تحم: } & ت & كلب & كلب & & مطلق & & كلب & & كلب & & 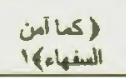 & ir \\
\hline & & رلّيَ & & & & & & & & & 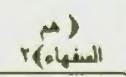 & it \\
\hline 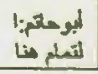 & ت & $|x|$ & تالم & & مطلت & & تلم & اكنى & تملم & حسن & (لا بطمون) & ir \\
\hline
\end{tabular}


تطور عم الموتف والابتداء في التدوين والكتابة وضبط المصاحف: مراسة موضو المية تطبيقية:

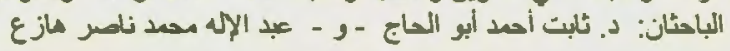

تابع سبرة البترة:

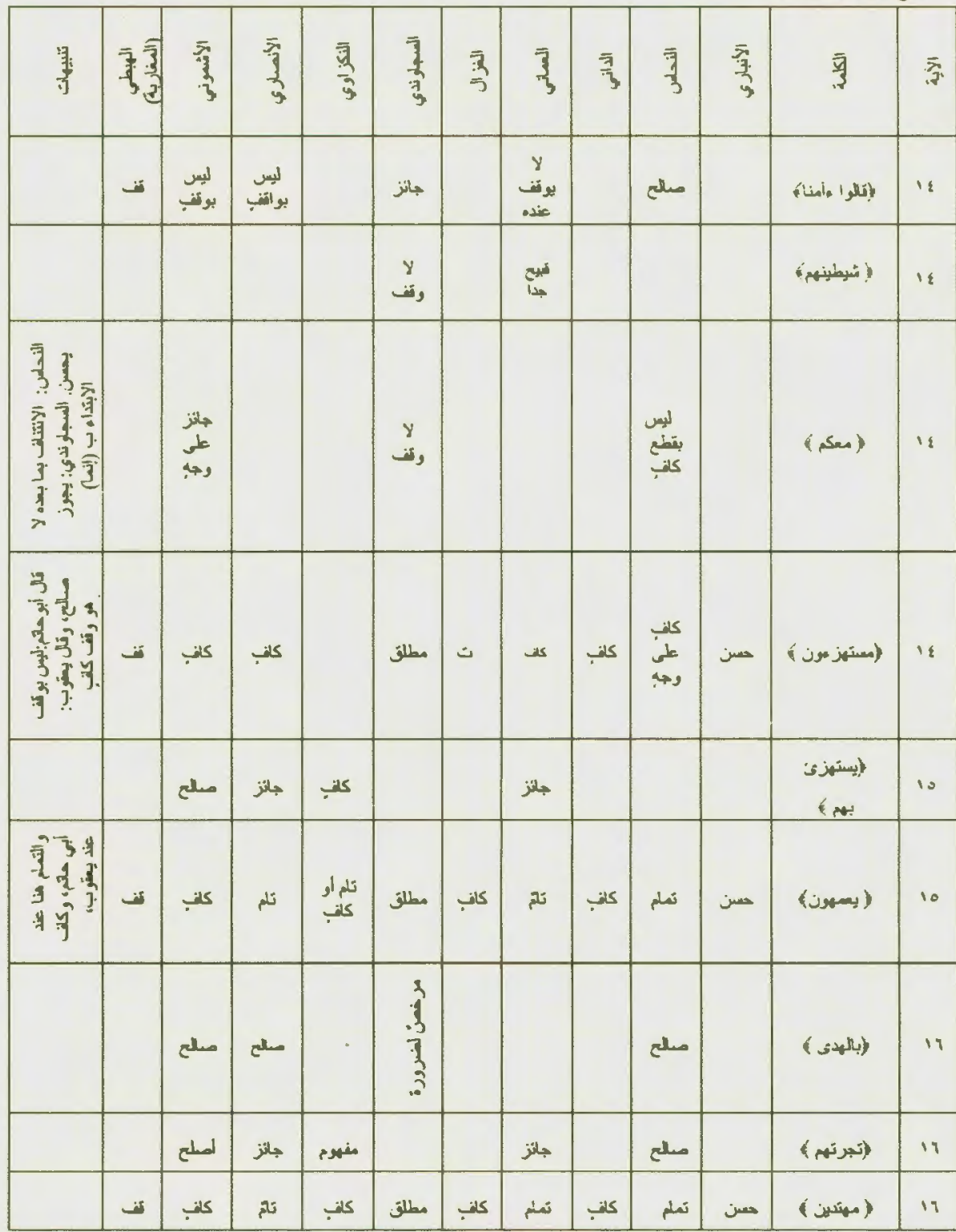




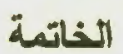

$$
\text { الحمد لله الذي بنعمته تتم الصَّالحات، وبعد: }
$$

في هذه الدراسة تناول الباحثان مفهوم الوقف وأنواعه، مع التذكير بأهمية هذا العلم وفوائده، ومعرفة الأدلة على مراعاته من الكتاب والسنة والإجماع،وعرّا بعلماء هذا الفنّ وجهودهم، والتي أدت لتطور علم الوقف والابتداء، وقد قام الباحثان بعمل درامة مقارنة- في المبحث الثالث- عن طريق عمل جداولٍ توضيحتة. لسورة الفاتحة والآيات الأولى من سورة البقرة - بيًَّا فيها المواضع التي الختلفت فيها

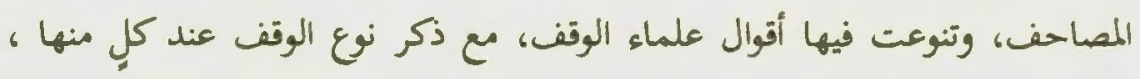
زيادةً في الإيضاح والتقريب والتسهيل والترتيب.

\section{وخلصت المراسة إلى نتائمع ، أهمها :}

ا. . معرفة الوقف والابتداء متأكدة غاية التأكيد؛ إذ لا يتبين معنى كلام اللّه ويتمّ على أكمل وجه إلا بذلك، فرب قارئ يقراً ويقف قبل تمام المعنى، فلا يفهم هو ما

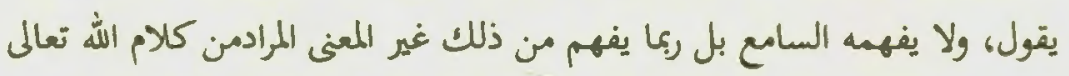
إذا وقف على غير موطن وقف، وهذا فساد عظيم، وخطر جسيم، لا تصع به القراءة، ولا تحل به التلاوة.

r. إن بحال الوقف والابتداء بحال خصبّ وواسعُ، والاجتهاد فيه محمود ما توافرت الضوابط الشُرعية والعلوم العربية،وقد جاء في التقرير العلمي لمصاحف المدينة

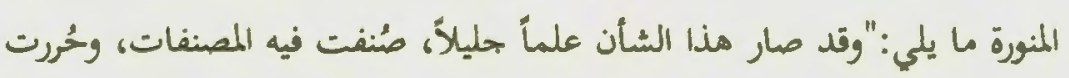

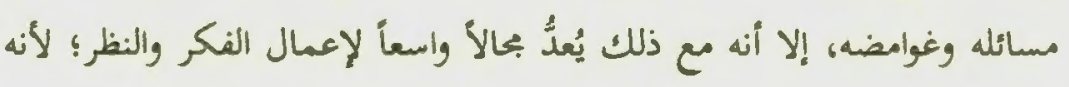


يُبنى على الاجتهاد في فَهم معاني الآيات القرآنية، واستكشاف مراميها، وبتحلية (1)". غورامئه

r. وخلاصة الكلام أن علماء هذا الفن - رحمهم الله تعالى - قد أختلفوا في أقسامه

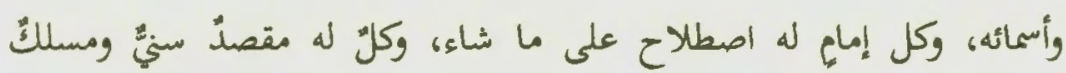

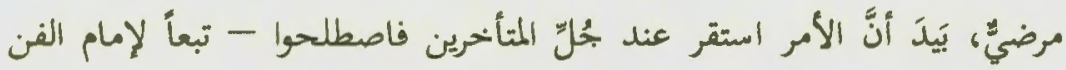

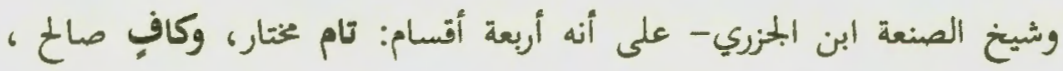

\section{وحسن مفهوم ، وقبيع متروك.}

\section{ويوصي الباحثان بما بإئ:}

يرى الباحثان ضرورة التزام مشايخ الإقراء بالشرط الذي وضعه أسلافهم، وهو أن على البجيز أن لا يجيز أحداً إلا بعد معرفته بهذا العلم؛ إذ الإخحلال به خلل في القراءة، ونقص في التلاوة، وعيب في الترتيل ·

يقترح الباحثان أن تُقام دورات متخصصةٍ في الموامع والملمعات وسائر المؤسسات العلمية المتخصصة في تُعنى بهذا العلم من حينِ لآخر .

كما ويوصي الباحثان بضرورة الاعتناء بلراسة علم الوقف، ونشر مؤلفاته، وتحقيقها، والاهتمام بمذا العلم، وإبراز جهود علمائه، وأبحاثه في البحلات الدورية العالمية ، والتشبحيع على ذلك .

انظر: التقرير اللقيمي عن مصحف المدينة النبوية : د. عبد العزيز بن عبد الفتاخ قارئ -

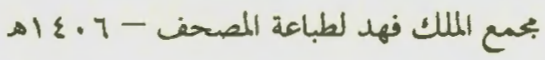


كما اقترح الباحث أن تُعمل دراسات مقارنة بين جهود المشارقة والمغاربة في هذا

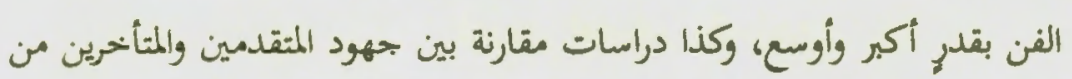

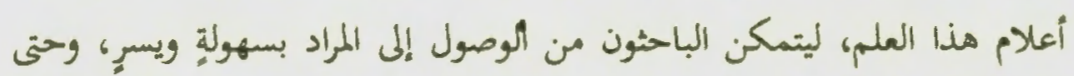

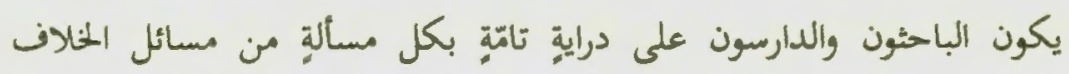
التفصيلية .

فهذه شجون وآمال ترجو أن تسعفها الههم العلية، والمقول الذكية، والقلوب

\section{(1)}




\section{فهرس المصاير وإلمراجع}

1- ابن الجزري (ت:بrrهـ)، شمس الدين محمد بن محمد، مراجعة وتصحيح

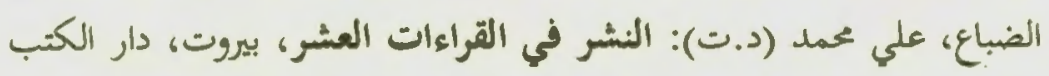

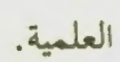

Y- ابن النحاس (ت:MrA

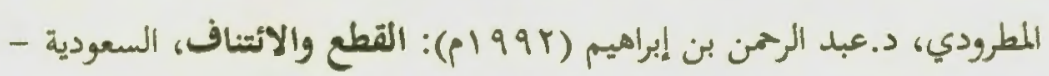

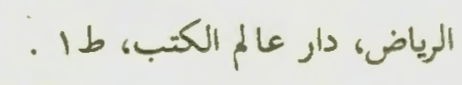

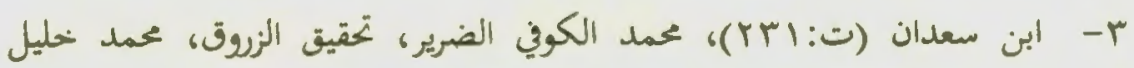

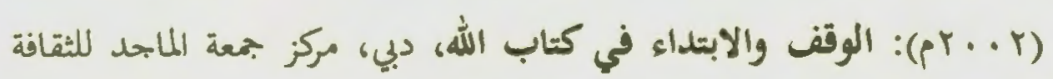

$$
\text { والتراث، ط ا. }
$$

ع- - ابن فارس (ت: موبهاث)، أبو الحسين أحمد الرازي، تحقيق هارون، عبد السلام

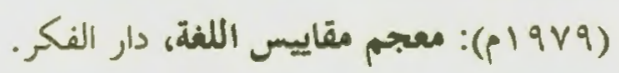

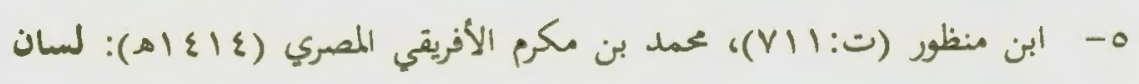

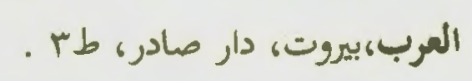

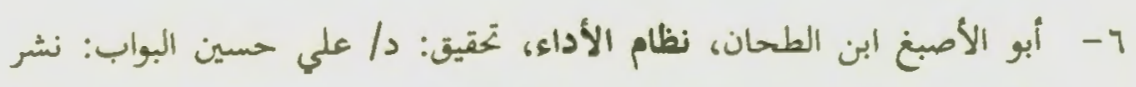

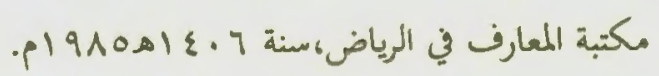

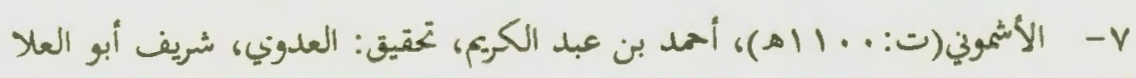

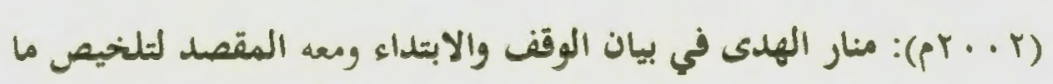

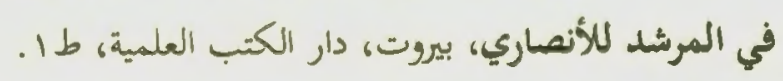


1- الأنصاري (ت:7 وهـ)، زكريا بن محمد، تحقيق: العدوي، شريف أبو العلا

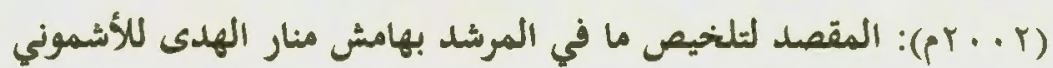

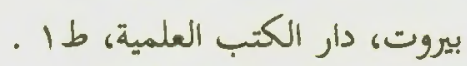

9- الداني، أبو عمر عثمان بن معيد، تحقيق المرعشلي، د.يوسف عبد الرحمن (91VV)

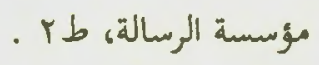

• ا- الذهبي، محمد بن أحمد بن عثمان بن قايماز الذهبي،معرفة القراء الكبار على

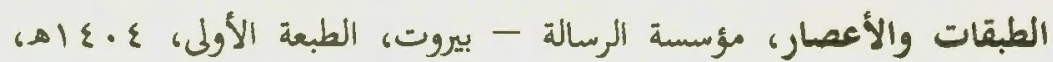
تحقيق: بشار عواد معروف, شعيب الأرناؤوط, صالخ مهدي عباس.

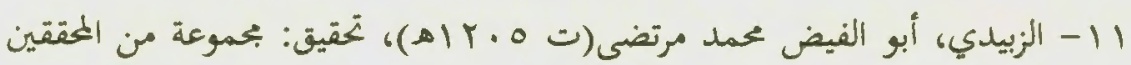
(د.ت): تاج العووس من جواهر القاموس، دار المداية.

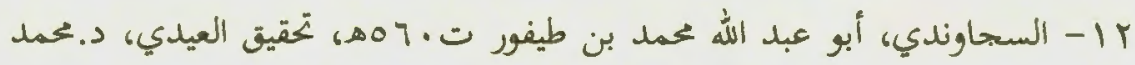
بن عبد الله، 7 . . ام، عل الوقوف، رسالة دكتوراه، جامعة الإمام، كلية

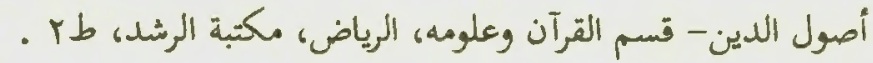
rا - السيوطي (ت:1119ه)، جلال الدين عبد الرحمن بن أبي بكر (د.ت): الدر المنثور في التفسير بالمأثور، بيروت، دار الفكر. ع 1 - ألسيوطي ت1 | 9،، جالال الدين عبد الرحمن بن أبي بكر، تحقيق، إبراهيم، محمد أبو الفضل، ع ع أم الإتقان في علوم القرآن، الهيئة المصرية العامة للكتاب. 1 - الصفاقسي (ت:11 | |هـ)، أبو الحسن علي بن محمد بن سلا لم النوري ، تحقيق، النيفر، محمد الشاذلي (د.ت): تنبيه الفافلين وإرشاد الجاهلين عما يقع لهم 
من الخطأ حال تلاوتهم لكتاب الله المبين، الناشر: مؤسسات عبد الكويم بن عبد الله.

\ا - الطيار، مساعد بن سليمان (آبـ اهـ ):وقوف القرآن وأثرها في التفسير،

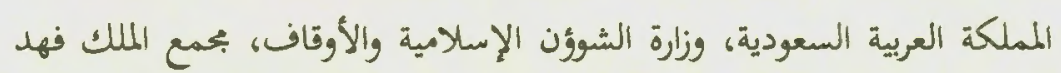

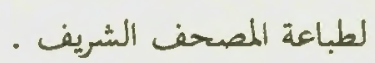

IV التراث في مؤسسة الرسالة بإشراف العرقومي، محمد نعيم (ه . . Yم): القاموس

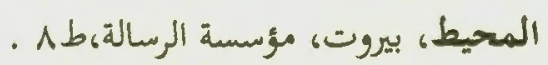

1 ا - قاري، د.عبد العزيز بن عبد الفتاح قارئ، التقرير العلمي عن مصحف الملدينة

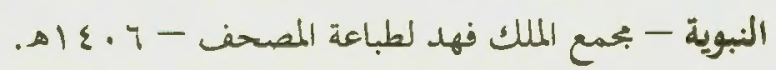
19 - والسخاوي، أبو الحسن علم الدين(ت: بع 7هـ) تحقيق العطية،د.مروان، وخرابة، د.محسن (997 (م): جمال القراء وكمال الإقراء، دمشق - دار المأمون للتراث، ط أن

تمَّ بحمد الله تعالى

1040 